\title{
58. GEOCHEMISTRY OF THE IGNEOUS ROCKS
}

\author{
B.M. Gunn and M.J. Roobol, Dépt. de Géologie, Université de Montreal
}

\section{LABORATORY METHODS}

Major and trace element analysis of 223 samples and 61 additional repeat analyses were made using a Philips $1220 \mathrm{X}$-ray fluorescence spectrometer. For the major elements, including sodium, $1.5 \mathrm{~g}$ of sample was fused into a glass disc with $3 \mathrm{~g}$ of lithium tetraborate and ground and polished to an optically flat surface. Trace element analyses were made on $3 \mathrm{~g}$ samples in pressed pellet form with a polyvinyl alcohol cement. Trace element analysis has so far been completed only for $\mathrm{Rb}$, $\mathrm{Sr}, \mathrm{Ba}$, and $\mathrm{Ni}$. An iterative matrix correction and data reduction were made either by a central CYBER computer or by an on-line PDP-11. Diagrams were plotted using a VERSATEK plotter. A measure of the precision is given by a comparison of 61 pairs of replicate analyses (Table 1). The samples were analyzed against USGS standard rock W-1 using the 1972 major element values (Flanagan, 1973) and trace element values of Abbey (1973). As an accuracy check further samples of standard rocks W-1 and AGV were run as unknowns and the results are shown in Table 2 . Interlaboratory analytical variation is discussed by Wright (this volume). The XRF analyses consistently show lower $\mathrm{Al}_{2} \mathrm{O}_{3}$ and slightly higher $\mathrm{Fe}_{2} \mathrm{O}_{3}$ than those analyzed by the classical wet chemical methods. We interpret these differences as resulting from the problems of separating the " $\mathrm{R}_{2} \mathrm{O}_{3}$ " group by wet methods.

Several samples have been taken from single 1.5meter-long sections of core, and some of these samples were analyzed in duplicate. The high level of precision indicated by the replicate analyses ${ }^{1}$ emphasizes the variations between samples from single core sections and the reader is referred to the listings of analyses, in particular: Hole 322A, Core 8, Section 1; Hole 332B, Core 19, Section 1; Hole 332B, Core 20, Section 3; Hole 332B, Core 21, Section 1; Hole 332B, Core 22, Section 4: Site 335, Core 9, Section 5.

The apparent variation of up to $\pm 0.5 \% \mathrm{MgO}$ within single core sections suggests that the samples taken

'Statistical treatment of sets of replicate analyses shows that of 53 shipboard analyses repeated at the Université de Montreal the correlation coefficients for the major analyses are all between 0.995 and 1.000 with slopes of between 0.917 and 1.02 . That is, there is little systematic error between the two sets of data. However, individual analyses differ by as much as $5 \% \mathrm{MgO}\left(=20 \%\right.$ absolute), $2 \% \mathrm{Al}_{2} \mathrm{O}_{3}$ $(=10 \%)$, and $3 \% \mathrm{SiO}_{2}(=6 \%)$. These samples are not identical being made on the same core material but not the same powders, so that the differences are largely due to sampling. The correlations between the 61 replicate analyses made at $U$. de $M$. are much higher, the mean error in $\mathrm{SiO}_{2}, \mathrm{Al}_{2} \mathrm{O}_{3}$, and $\Sigma \mathrm{Fe}_{2} \mathrm{O}_{3}$ being only $0.02 \%$ or less, while even the maximum replication error in $\mathrm{MgO}$ is less than $0.1 \% \mathrm{MgO}$ or $2.5 \%$ absolute.
TABLE 1

Replication Tests on 61 Pairs of Leg 37 XRF Analyses

\begin{tabular}{lcccc}
\hline & Mean & Av. Diff. & Av. \% Diff. & Max. Diff. \\
\hline $\mathrm{SiO}_{2}$ (wt \%) & 49.52 & 0.114 & 0.06 & 0.41 \\
$\mathrm{Al}_{2} \mathrm{O}_{3}$ (wt \%) & 15.80 & 0.076 & 0.12 & 0.55 \\
$\mathrm{TiO}_{2}$ (wt \%) & 0.860 & 0.006 & 0.17 & 0.022 \\
$\mathrm{\Sigma Fe}_{2} \mathrm{O}_{3}$ (wt \%) & 9.95 & 0.056 & 0.14 & 0.19 \\
$\mathrm{MnO}$ (wt \%) & 0.152 & 0.001 & 0.15 & 0.005 \\
$\mathrm{MgO}$ (wt \%) & 8.61 & 8.61 & 0.16 & 0.22 \\
$\mathrm{CaO}$ (wt \%) & 12.75 & 0.072 & 0.14 & 0.29 \\
$\mathrm{Na}_{2} \mathrm{O}$ (wt \%) & 2.025 & 0.049 & 0.61 & 0.12 \\
$\mathrm{~K}_{2} \mathrm{O}$ (wt \%) & 0.210 & 0.002 & 0.19 & 0.005 \\
$\mathrm{P}_{2} \mathrm{O}_{5}$ (wt \%) & 0.100 & 0.004 & 1.0 & 0.01 \\
$\mathrm{Ni}^{\mathrm{a}}$ (ppm) & 166.7 & 2.2 & 1.1 & 5.4 \\
$\mathrm{Rb}^{\mathrm{b}}$ (ppm) & 3.8 & 0.35 & 7.0 & 3.5 \\
$\mathrm{Sr}^{\mathrm{c}}$ (ppm) & 106.3 & 0.5 & 0.6 & 5.2 \\
$\mathrm{Ba}^{\mathrm{d}}$ (ppm) & 63.5 & 5.0 & 6.0 & 18.0 \\
\hline
\end{tabular}

${ }^{a}$ Calculated for 37 pairs of replicates only.

${ }^{b}$ Calculated for 15 pairs of replicates only.

${ }^{c}$ Calculated for 15 pairs of replicates only.

${ }^{d}$ Calculated for 37 pairs of replicates only.

from them were too small and not fully representative. This is unfortunate as it introduces an error into the study, e.g., in the above example from Site 335 where the composition of the section lies close to $16 \% \mathrm{Al}_{2} \mathrm{O}_{3}$ (which is taken as the lower limit for the plagioclase basalts) the variation caused by inadequate sampling results in two rock names being applied to this single 1.5 -meter-long core. Some of the variation in $\mathrm{MgO}$ is due to the introduction of magnesium carbonates into the basalts.

With regard to the problem of alteration of the samples, examination of the 54 thin sections available to us shows that as much as $50 \%$ of certain samples is made up of devitrified glass often showing quench textures of skeletal plagioclase and dendritic (spinifex) textured pyroxene. Such glass is highly unstable and prone to alteration to zeolite and other minerals (Rex, 1967). Vesicles in some samples are lined with fibrous smectite and illite or filled with calcite, while pyroxene may also be altered. Nevertheless, only seven of the Montreal samples have excessively high $\mathrm{K}_{2} \mathrm{O}, \mathrm{Rb}$, or $\mathrm{Ba}$ which is unrelated to any obvious fractionation or partial melt series and so probably represent alteration.

\section{GEOCHEMISTRY}

All of the analyzed samples are flows, breccias, or dikes except for 10 of gabbro-eucrite-peridotite from the bottom of Site 334. All are of basaltic type in the 
TABLE 2

Compositions of Standard Rocks Analyzed as Unknowns Against W-1 Deep Drill, Leg 37, Check Standards

\begin{tabular}{|c|c|c|c|c|c|c|c|c|c|c|c|}
\hline & W-1 & DDW-11 & DDW-14 & DDW-15 & DDW-16 & DDW-17 & AGV-1 & DDAGV1 & DDAGV3 & DDAGV4 & DTS1 \\
\hline $\mathrm{SiO}_{2}$ & 52.39 & 52.23 & 52.14 & 52.12 & 52.12 & 52.12 & 60.29 & 60.22 & 60.18 & 60.03 & 40.72 \\
\hline $\mathrm{Al}_{2} \mathrm{O}_{3}$ & 14.93 & 14.96 & 14.87 & 14.95 & 14.95 & 14.95 & 17.43 & 17.42 & 17.50 & 17.71 & 0.24 \\
\hline $\mathrm{TiO}_{2}$ & 1.065 & 1.075 & 1.077 & 1.074 & 1.074 & 1.074 & 1.066 & 1.070 & 1.049 & 1.070 & 0.013 \\
\hline $\mathrm{Fe}_{2} \mathrm{O}_{3}$ & 11.040 & 10.990 & 11.230 & 11.110 & 11.110 & 11.110 & 6.828 & 6.830 & 6.850 & 6.750 & 8.687 \\
\hline $\mathrm{MnO}$ & 0.169 & 0.169 & 0.171 & 0.169 & 0.169 & 0.169 & 0.102 & 0.102 & 0.095 & 0.099 & 0.111 \\
\hline $\mathrm{MgO}$ & 6.59 & 6.58 & 6.66 & 6.62 & 6.62 & 6.62 & 1.52 & 1.64 & 1.59 & 1.60 & 50.07 \\
\hline $\mathrm{CaO}$ & 10.910 & 11.030 & 10.980 & 11.080 & 11.080 & 11.080 & 5.015 & 5.070 & 4.990 & 5.070 & 0.151 \\
\hline $\mathrm{Na}_{2} \mathrm{O}$ & 2.140 & 2.170 & 2.100 & 2.110 & 2.110 & 2.110 & 4.317 & 4.210 & 4.330 & 4.240 & 0.007 \\
\hline $\mathrm{K}_{2} \mathrm{O}$ & 0.637 & 0.645 & 0.642 & 0.639 & .639 & 0.638 & 2.932 & 2.939 & 2.953 & 2.954 & 0.001 \\
\hline $\mathrm{P}_{2} \mathrm{O}_{5}$ & 0.139 & 0.150 & 0.130 & 0.130 & .130 & 0.130 & 0.504 & 0.510 & 0.460 & 0.480 & 0.002 \\
\hline Total & 100.008 & 99.999 & 100.00 & 100.02 & 100.02 & 100.002 & 100.002 & 100.009 & 99.997 & 100.003 & 100.003 \\
\hline $\mathrm{Ni}$ & 78.0 & 77.3 & 0.0 & 79.4 & 67.7 & 82.5 & 27.0 & 0.0 & 19.9 & 0.0 & 2348.0 \\
\hline $\mathrm{Rb}$ & 22.0 & 0.0 & 23.1 & 21.8 & 23.2 & 21.8 & 69.0 & 72.9 & 68.3 & 74.1 & 0.2 \\
\hline Sr & 185.0 & 0.0 & 184.5 & 185.0 & 185.8 & 183.1 & 664.0 & 662.3 & 656.3 & 660.1 & 0.4 \\
\hline $\mathrm{Ba}$ & 160.0 & 159.7 & 0.0 & 155.9 & 158.3 & 160.3 & 1242.0 & 0.0 & 0.0 & 0.0 & 14.9 \\
\hline
\end{tabular}

CIPW Norms

\begin{tabular}{lrrrrrrrrrrr} 
Qz & 5.32 & 4.90 & 5.01 & 4.91 & 4.91 & 4.91 & 10.25 & 10.45 & 9.81 & 9.96 & 0.00 \\
Or & 3.76 & 3.81 & 3.79 & 3.78 & 3.78 & 3.78 & 17.33 & 17.37 & 17.45 & 17.46 & 0.00 \\
Plag & 47.36 & 47.54 & 47.02 & 47.29 & 47.29 & 47.29 & 56.05 & 55.58 & 56.23 & 56.45 & 0.68 \\
Di & 19.59 & 20.08 & 19.92 & 20.17 & 20.17 & 20.17 & 2.01 & 1.84 & 2.06 & 1.47 & 0.09 \\
Hy & 16.82 & 16.49 & 17.02 & 16.67 & 16.67 & 16.67 & 8.25 & 8.64 & 8.64 & 8.45 & 3.31 \\
Ol & 0.00 & 0.00 & 0.00 & 0.00 & 0.00 & 0.00 & 0.00 & 0.00 & 0.00 & 0.00 & 92.09 \\
Mt & 4.00 & 3.98 & 4.07 & 4.03 & 4.03 & 4.03 & 2.47 & 2.48 & 2.48 & 2.45 & 3.15 \\
Il & 2.02 & 2.04 & 2.05 & 2.04 & 2.04 & 2.04 & 2.02 & 2.03 & 1.99 & 2.03 & 0.02 \\
Ap & 0.30 & 0.33 & 0.28 & 0.28 & 0.28 & 0.28 & 1.10 & 1.11 & 1.00 & 1.05 & 0.00 \\
Total & 99.18 & 99.17 & 99.16 & 99.17 & 99.17 & 99.17 & 99.49 & 99.50 & 99.48 & 99.50 & 99.35 \\
An\% & 60.4 & 60.0 & 60.8 & 60.8 & 60.8 & 60.8 & 33.5 & 34.6 & 33.5 & 35.1 & 90.8 \\
\hline
\end{tabular}

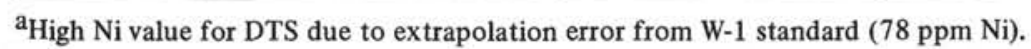

range $47 \%-51 \% \mathrm{SiO}_{2}$. Most abundant are the olivine to quartz normative tholeiites forming a series of apparently primary magmas ranging from $7 \%$ to $9 \%$ $\mathrm{MgO}$, though with increasing $\mathrm{MgO}$ content it becomes difficult to distinguish primary magma from an olivine cumulate. The $\mathrm{Fe}_{2} \mathrm{O}_{3}$ (total iron)- $\mathrm{MgO}$ diagram (Figure 1) illustrates this variation with the greatest density of points representing the aphyric and sparsely phyric tholeiite field, from which several olivine-enriched (up to $20 \% \mathrm{MgO}$ ) and depleted (down to $6 \% \mathrm{MgO}$ ) series arise. Apparently unrelated to the main group are plagioclase-enriched basalts and the gabbro-eucriteperidotites of Site 334. The crystal fractionated series have been separated from the undifferentiated tholeiite using the variation diagrams and the following terms applied throughout this report.

Picritic basalts have 9\%-15\% MgO, picrites $15 \%-20 \%$ $\mathrm{MgO}$, and plagioclase basalts more than $16 \% \mathrm{Al}_{2} \mathrm{O}_{3}$. These terms are based solely on chemical parameters and do not necessarily reflect the phenocryst mineralogy. A distinct group of low-Mg flows (Figure 1, less than $6.1 \% \mathrm{MgO}$ ) have been termed low- $\mathrm{Mg}$ plagioclase basalts but are altered rocks. Several of these series can be further subdivided, but each broad group is first described separately, regardless of the hole and age, as indicating magmatic processes operating under the ocean ridge.

\section{Undifferentiated Tholeiites}

Ninety-eight or $44 \%$ of the 223 analyzed samples (plus 27 repeats) are undifferentiated tholeiite or MORB (Mid-Ocean-Ridge Basalt). Average analyses of the major magma types are listed in Table 3. The group has a limited range of $\mathrm{SiO}_{2}(48 \%-51.5 \%), \mathrm{Al}_{2} \mathrm{O}_{3}$ ( $14.29 \%$ to the limit at $16 \%), \mathrm{Na}_{2} \mathrm{O}(1.68 \%-2.68 \%)$ and a wider spread of $\mathrm{TiO}_{2}(0.633 \%-1.493 \%), \Sigma \mathrm{Fe}_{2} \mathrm{O}_{3}(9.09 \%$ $12.10 \%), \mathrm{MnO}(0.143 \%-0.281 \%), \mathrm{MgO}(6.84 \%$ to the limit at $9.0 \%), \mathrm{CaO}(10.81 \%-15.94 \%), \mathrm{K}_{2} \mathrm{O}(0.084 \%$ $0.469 \%$ and a few higher values in altered rocks), and $\mathrm{P}_{2} \mathrm{O}_{5}(0.07 \%-0.19 \%)$. These variations are systematic for some element pairs, e.g., $\mathrm{P}_{2} \mathrm{O}_{5}-\mathrm{TiO}_{2}$ (Figure 2). However, the amounts of the incompatible elements $\mathrm{TiO}_{2}, \mathrm{~K}_{2} \mathrm{O}, \mathrm{P}_{2} \mathrm{O}_{5}, \mathrm{Sr}$, and $\mathrm{Rb}$ increase sharply with decrease in $\mathrm{MgO}$. The increases are of up to a factor of two and cannot be accounted for by dilution by accumulation of phenocryst minerals, in particular olivine. It is inferred that these basalts probably 
TABLE 2 - Continued

\begin{tabular}{lcccccll}
\hline & DDTS1 & DDDTS2 & BCR1 & DDBCR2 & W-1 & Diabase, USGS & Standard value used in this paper \\
\hline $\mathrm{SiO}_{2}$ & 41.31 & 41.10 & 54.71 & 54.38 & DDW-11 & Diabase, USGS & Major and trace check standard \\
$\mathrm{Al}_{2} \mathrm{O}_{3}$ & 0.30 & 0.31 & 13.67 & 14.04 & DDW-14 & Diabase, USGS & Major and trace check standard \\
$\mathrm{TiO}_{2}$ & 0.000 & 0.009 & 2.209 & 2.243 & DDW-15 & Diabase, USGS & Major and trace check standard \\
$\mathrm{Fe}_{2} \mathrm{O}_{3}$ & 9.150 & 9.100 & 13.450 & 13.120 & DDW-16 & Diabase, USGS & Trace element check standard \\
$\mathrm{MnO}$ & 0.132 & 0.131 & 0.181 & 0.180 & DDW-17 & Diabase, USGS & Trace element check standard \\
$\mathrm{MgO}$ & 48.87 & 49.04 & 3.47 & 3.56 & AGV1 & Andesite, USGS & Standard value used in this paper \\
$\mathrm{CaO}$ & 0.180 & 0.170 & 6.943 & 7.070 & PPAGV1 & Andesite, USGS & Major and trace check standard \\
$\mathrm{Na}_{2} \mathrm{O}$ & 0.060 & 0.130 & 3.283 & 3.320 & DDAGV3 & Andesite, USGS & Major and trace check standard \\
$\mathrm{K}_{2} \mathrm{O}$ & 0.001 & 0.001 & 1.707 & 1.723 & DDAGV4 & Andesite, USGS & Major and trace check standard \\
$\mathrm{P}_{2} \mathrm{O}_{5}$ & 0.010 & 0.000 & 0.361 & 0.360 & & & \\
$\mathrm{Total}$ & 100.022 & 99.991 & 99.988 & 99.996 & DTS1 & Dunite, USGS & Standard value used in this paper \\
$\mathrm{Ni}$ & $2725.8^{\mathrm{a}}$ & $2739.9 \mathrm{a}$ & 20.0 & 0.0 & DDDTS1 & Dunite, USGS & Major and trace check standard \\
$\mathrm{Rb}$ & 0.1 & 0.3 & 49.0 & 48.5 & DDDTS2 & Dunite, USGS & Major and trace check standard \\
$\mathrm{Sr}$ & 0.3 & 0.9 & 335.0 & 325.0 & BCR1 & Basalt, USGS & Standard value used in this paper \\
$\mathrm{Ba}$ & 12.2 & 25.2 & 725.0 & 0.0 & BCR2 & Basalt, USGS & Major and trace check standard
\end{tabular}

$\begin{array}{lrrrr}\text { Qz } & 0.00 & 0.00 & 8.32 & 7.46 \\ \text { Or } & 0.01 & 0.01 & 10.09 & 10.18 \\ \text { Plag } & 1.05 & 1.36 & 45.30 & 46.41 \\ \text { Di } & 0.23 & 0.46 & 12.33 & 12.17 \\ \text { Hy } & 6.83 & 4.43 & 13.08 & 12.99 \\ \text { O1 } & 87.87 & 89.73 & 0.00 & 0.00 \\ \text { Mt } & 3.32 & 3.30 & 4.88 & 4.76 \\ \text { Il } & 0.02 & 0.02 & 4.20 & 4.26 \\ \text { Ap } & 0.02 & 0.00 & 0.79 & 0.79 \\ \text { Total } & 99.34 & 99.31 & 98.98 & 99.01 \\ \text { An\% } & 50.4 & 18.2 & 37.3 & 38.1\end{array}$

represent magmas generated under different pressures by the partial melting of a mantle parent.

The undifferentiated tholeiites tend to be chemically grouped both by hole and by stratigraphic unit. Thus all from Site 334 have less than $1 \% \mathrm{TiO}_{2}$, while all from Site 335 and all but two from Hole 332A have more. Again, all the tholeiites from Hole 332A are quartz normative, while the other holes have lengthy stratigraphic sections of olivine normative type. In Hole 332B, high- and low-Ti tholeiites alternate. The abundance of tholeiites of differing $\mathrm{Ti}$ content is not random, and if all the tholeiites from all holes are regarded together there are distinct clusterings, e.g., the $\mathrm{P}_{2} \mathrm{O}_{5}-\mathrm{TiO}_{2}$ diagram (Figure 2), also the $\mathrm{Sr}-\mathrm{TiO}$, $\mathrm{Sr}$ $\mathrm{Na} 2 \mathrm{O}$, and $\mathrm{Sr}-\mathrm{CaO}$ diagrams. We have subdivided the tholeiites into four groups according to $\mathrm{TiO}_{2}$ content. They are referred to as type 1 (with less than $0.85 \%$ $\left.\mathrm{TiO}_{2}\right)$, type $2\left(0.85\right.$ to $\left.1.0 \% \mathrm{TiO}_{2}\right)$, type $3(1.0$ to $1.2 \%$ $\mathrm{TiO}_{2}$ ), and type 4 (more than $1.2 \% \mathrm{TiO}_{2}$ ). Type 3 can be further subdivided into high-and low-Sr subgroups divided by a gap at about $100 \mathrm{ppm} \mathrm{Sr}$. Basalts of the lower $\mathrm{Sr}$ subgroup have between 80 and $100 \mathrm{ppm} \mathrm{Sr}$ while those of the higher subgroup have 105 to $125 \mathrm{ppm}$ Sr. The tholeiites or the plots of their average compositions comprise a trend which can be extrapolated on variation diagrams (e.g., $\mathrm{P}_{2} \mathrm{O}_{5}-\mathrm{TiO}_{2}$,
$\mathrm{Sr}-\mathrm{TiO}_{2}$ ) towards other possible parental liquids of more basic composition, which would be extremely depleted in the incompatible elements as well as iron.

As a whole, the undifferentiated tholeiites can be regarded as being the low end of the tholeiitetransitional basalt-alkali basalt-basanite-limburgite series (Gunn and Watkins, in press, fig. 13). Hawaiian tholeiites which are relatively more "alkaline" than the MORB have more than twice the $\mathrm{TiO}_{2}(2.5 \%), \mathrm{P}_{2} \mathrm{O}_{5}$ $(0.22 \%)$, and $\mathrm{Sr}(330 \mathrm{ppm})$. These latter values again contrast strongly with basanites with $2.3 \% \mathrm{TiO}_{2}, 1.3 \%$ $\mathrm{P}_{2} \mathrm{O}_{5}$, and $1400 \mathrm{ppm} \mathrm{Sr}$.

\section{Plagioclase Basalts}

Eighty of the analyzed samples (36\%) are plagioclase basalts with $16.0 \%-24.04 \% \mathrm{Al}_{2} \mathrm{O}_{3}$. Three main groups are present, one consisting of undifferentiated highalumina basalt of more than $0.7 \% \mathrm{TiO}_{2}$ and the others made up of lower $\mathrm{Ti}$ rocks showing two series of plagioclase cumulates (Figure 3). Fourteen of the analyzed samples have between $0.328 \%-0.564 \% \mathrm{TiO}_{2}$, $5.32 \%-8.54 \% \Sigma \mathrm{Fe}_{2} \mathrm{O}_{3}$, and $0.04 \%-0.08 \% \mathrm{P}_{2} \mathrm{O}_{5}$, while 64 have between $0.756 \%-1.171 \% \quad \mathrm{TiO}_{2}, \quad 8.97 \%-10.93 \%$ $\Sigma \mathrm{Fe}_{2} \mathrm{O}_{3}$, and $0.07 \%-0.14 \% \mathrm{P}_{2} \mathrm{O}_{5}$ and have been termed low- and high-Ti, plagioclase basalts, respectively. The 5 low-Mg plagioclase basalts mentioned previously 


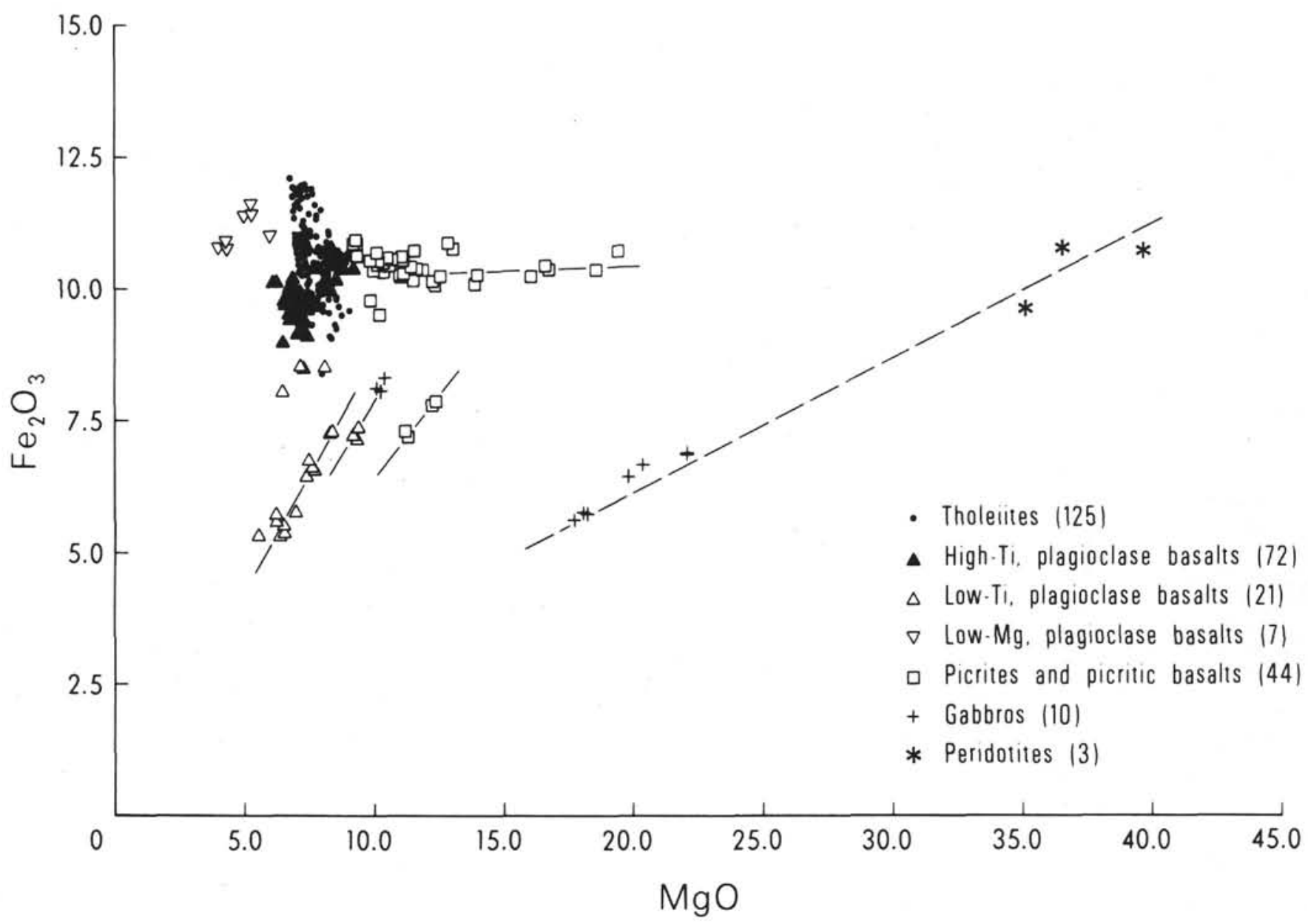

Figure 1. $\mathrm{SFe}_{2} \mathrm{O}_{3}-\mathrm{MgO}$ diagram for 282 analyses of Holes $332 \mathrm{~A}, 332 \mathrm{~B}, 332 \mathrm{D}, 333 \mathrm{~A}$, and Sites 334 and 335 .

have $0.803 \%-0.855 \% \mathrm{TiO}_{2}, 10.81 \%-11.63 \% \Sigma \mathrm{Fe}_{2} \mathrm{O}_{3}$, and $0.10 \%-0.15 \% \mathrm{P}_{2} \mathrm{O}_{s}$. Apart from $\mathrm{MgO}$, these are similar to the high-Ti, plagioclase basalts, but in these rocks the pyroxene is completely broken down to iron chlorite and a smectite, and considerable change in bulk composition has taken place. The covariance of $\mathrm{TiO}_{2}$ and $\mathrm{P}_{2} \mathrm{O}_{5}$ is similar to that already encountered in the undifferentiated tholeiites and is also attributed to variations in the composition of the primary melts. On the $\mathrm{Al}_{2} \mathrm{O}_{3}-\mathrm{TiO}_{2}$ diagram (Figure 3) the low-Ti, plagioclase basalts appear as two separate subseries trending subparallel toward $33 \% \mathrm{Al}_{2} \mathrm{O}_{3}$, while on other diagrams, e.g., $\mathrm{CaO}-\mathrm{MgO}$ and $\mathrm{CaO}-\mathrm{TiO}_{2}$, they trend towards $15 \% \mathrm{Ca}$ indicating that the low-Ti series is the result of plagioclase accumulation of a bulk composition around bytownite. The division of the low-Ti, plagioclase basalts into two subseries is justified by their stratigraphic occurrence in Holes $332 \mathrm{~A}$ and 332B at distinct and correlatable horizons as discussed in the section on geochemical stratigraphy in this report.

The 64 high-Ti, plagioclase basalts form a group of probable primary melts of increasing $\mathrm{TiO}_{2}, \mathrm{P}_{2} \mathrm{O}_{5}$, and $\mathrm{Sr}$ at constant or slightly decreasing $\mathrm{Al}_{2} \mathrm{O}_{3}$ (Figure 3). Variation diagrams with $\mathrm{CaO}$ show the group as a cluster of points. This suggests that rather than being a simple series resulting from plagioclase depletion of undifferentiated tholeiite (a suggestion also at variance with their high $\mathrm{Al}_{2} \mathrm{O}_{3}$ content), the apparent trend is a composite of several distinct primary melts equating with distinct stratigraphic units. Each of these has a higher $\mathrm{Al}_{2} \mathrm{O}_{3}$ content than the undifferentiated tholeiites, but is otherwise similar. The primary melt suggestion is further supported by plotting the average compositions of the six stratigraphic units which comprise this apparently simple trend. The four subseries of the plagioclase basalts can again be recognized on the $\mathrm{TiO}_{2}-\mathrm{MgO}$ diagram (Figure 4).

The characteristics of rock series formed by fractionation of calcic feldspar from plagioclase tholeiites has been described by Gunn et al. (1975). The difficulty in deriving regular trends, e.g., for $\mathrm{Sr}$ fractionation, from dredged oceanic crust material is now explained. While the high-alumina dredged rocks were plagioclase cumulates, other dredged rocks of $14 \%$ to $17 \% \mathrm{Al}_{2} \mathrm{O}_{3}$ from the same location were not necessarily related to the series. Instead of being Srdepleted as was to be expected in a residual member of the series, anomalous samples could be unrelated high$\mathrm{Ti}$, high-Sr, undifferentiated basalts. The $\mathrm{Sr}-\mathrm{Al}_{2} \mathrm{O}_{3}$ relationship in the plagioclase fractionated members of the present Leg 37 basalts is simple and is as predicted 
TABLE 3

Average compositions for rock types calculated with Montreal analyses from all Leg 37 holes

\begin{tabular}{|c|c|c|c|c|c|c|c|c|c|c|c|c|c|c|c|}
\hline No. & 1 & 2 & 3 & 4 & 5 & 6 & 7 & 8 & 9 & 10 & 11 & 12 & 13 & 14 & 15 \\
\hline $\mathrm{SiO}_{2}$ & 50.58 & 50.58 & 50.21 & 49.66 & 48.69 & 49.19 & 50.14 & 46.14 & 47.04 & 48.83 & 48.26 & 44.55 & 50.71 & 50.85 & 48.39 \\
\hline $\mathrm{Al}_{2} \mathrm{O}_{3}$ & 15.15 & 15.05 & 15.22 & 15.03 & 19.89 & 16.89 & 16.42 & 17.02 & 12.73 & 15.09 & 15.07 & 4.75 & 15.58 & 12.32 & 11.14 \\
\hline $\mathrm{TiO}_{2}$ & 0.746 & 0.907 & 1.113 & 1.286 & 0.437 & 0.853 & 1.019 & 0.834 & 0.524 & 0.775 & 0.584 & 0.051 & 0.145 & 0.086 & 0.069 \\
\hline $\mathrm{Fe}_{2} \mathrm{O}_{3}$ & 9.91 & 10.37 & 10.67 & 11.62 & 6.66 & 10.16 & 9.68 & 11.14 & 10.42 & 10.43 & 9.89 & 10.38 & 8.18 & 5.73 & 6.73 \\
\hline $\mathrm{MnO}^{\circ}$ & 0.165 & 0.177 & 0.164 & 0.174 & 0.112 & 0.148 & 0.150 & 0.174 & 0.151 & 0.148 & 0.147 & 0.141 & 0.168 & 0.121 & 0.142 \\
\hline $\mathrm{MgO}$ & 8.31 & 7.77 & 7.60 & 7.28 & 7.24 & 7.69 & 7.27 & 4.95 & 17.54 & 10.37 & 11.75 & 37.07 & 10.26 & 18.05 & 21.08 \\
\hline $\mathrm{CaO}$ & 13.03 & 12.72 & 12.42 & 12.24 & 15.25 & 12.44 & 12.94 & 16.54 & 9.72 & 12.09 & 12.26 & 2.91 & 13.73 & 12.32 & 12.10 \\
\hline $\mathrm{Na}_{2} \mathrm{O}$ & 1.84 & 2.08 & 2.21 & 2.22 & 1.56 & 2.30 & 2.06 & 2.61 & 1.68 & 1.98 & 1.83 & 0.12 & 1.18 & 0.50 & 0.29 \\
\hline $\mathrm{K}_{2} \mathrm{O}$ & 0.191 & 0.236 & 0.273 & 0.309 & 0.101 & 0.228 & 0.215 & 0.462 & 0.152 & 0.198 & 0.145 & 0.020 & 0.021 & 0.014 & 0.048 \\
\hline $\mathrm{P}_{2} \mathrm{O}_{5}$ & 0.08 & 0.10 & 0.13 & 0.17 & 0.05 & 0.09 & 0.12 & 0.13 & 0.05 & 0.09 & 0.06 & 0.02 & 0.02 & 0.02 & 0.02 \\
\hline TOTAL & 100.002 & 99.990 & 100.010 & 99.989 & 99.990 & 99.989 & 100.014 & 100.000 & 100.007 & 100.001 & 99.996 & 100.012 & 99.994 & 100.011 & 100.009 \\
\hline $\mathrm{Ni}$ & 145.8 & 112.5 & 112.8 & 87.9 & 114.9 & 119.6 & 94.4 & 141.2 & 658.4 & 274.2 & 356.6 & 1823.0 & 152.9 & 456.2 & 729.3 \\
\hline $\mathrm{Rb}$ & 3.5 & 4.3 & 4.5 & 5.5 & 1.8 & 4.0 & 3.9 & 4.2 & 2.7 & 3.3 & 2.4 & 0.8 & 1.2 & 0.5 & 1.0 \\
\hline $\mathrm{Sr}$ & 77.5 & 97.3 & 107.4 & 117.4 & 96.2 & 93.2 & 115.0 & 129.5 & 69.5 & 107.9 & 98.7 & 3.7 & 30.2 & 11.4 & 13.3 \\
\hline $\mathrm{Ba}$ & 65.7 & 74.9 & 74.4 & 76.8 & 45.2 & 60.0 & 72.4 & 57.7 & 47.2 & 55.0 & 47.6 & 53.0 & 45.1 & 53.5 & 59.3 \\
\hline \multicolumn{16}{|c|}{ C.I.P.W NORMS } \\
\hline $\mathrm{Qz}$ & 1.64 & 1.45 & 0.87 & 0.66 & 0.00 & 0.00 & 1.33 & 0.00 & 0.00 & 0.00 & 0.00 & 0.00 & 1.88 & 0.00 & 0.00 \\
\hline Or & 1.13 & 1.39 & 1.61 & 1.83 & 0.60 & 1.35 & 1.27 & 2.73 & 0.90 & 1.17 & 0.86 & 0.12 & 0.12 & 0.08 & 0.28 \\
\hline Plag & 48.09 & 48.63 & 49.51 & 48.92 & 60.17 & 54.55 & 52.36 & 40.57 & 40.96 & 48.46 & 47.96 & 13.38 & 47.14 & 35.56 & 31.41 \\
\hline $\mathrm{Ne}$ & 0.00 & 0.00 & 0.00 & 0.00 & 0.00 & 0.00 & 0.00 & 8.06 & 0.00 & 0.00 & 0.00 & 0.00 & & & \\
\hline Di & 25.56 & 25.48 & 24.33 & 24.04 & 22.78 & 21.12 & 23.10 & 39.44 & 16.85 & 22.30 & 22.42 & 1.54 & 24.72 & 23.41 & 24.43 \\
\hline Hy & 17.66 & 16.55 & 16.63 & 16.65 & 10.32 & 12.56 & 15.53 & 0.00 & 10.09 & 14.02 & 10.78 & 26.39 & 22.23 & 34.13 & 22.90 \\
\hline $\mathrm{Ol}$ & 0.00 & 0.00 & 0.00 & 0.00 & 2.26 & 4.15 & 0.00 & 2.46 & 25.54 & 7.82 & 12.40 & 53.91 & 0.00 & 4.12 & 17.87 \\
\hline Mt & 3.59 & 3.76 & 3.87 & 4.21 & 2.41 & 3.68 & 3.51 & 4.04 & 3.78 & 3.78 & 3.58 & 3.76 & 2.97 & 2.08 & 2.44 \\
\hline Il & 1.42 & 1.72 & 2.11 & 2.44 & 0.83 & 1.62 & 1.94 & 1.58 & 1.00 & 1.47 & 1.11 & 0.10 & 2.97 & 2.08 & 0.13 \\
\hline Ap & 0.17 & 0.22 & 0.28 & 0.37 & 0.11 & 0.20 & 0.26 & 0.28 & 0.11 & 0.20 & 0.13 & 0.04 & 0.04 & 0.04 & 0.04 \\
\hline TOTAL & 99.26 & 99.21 & 99.21 & 99.12 & 99.49 & 99.23 & 99.29 & 99.16 & 99.23 & 99.22 & 99.25 & 99.23 & 99.38 & 99.58 & 99.51 \\
\hline An $\%$ & 66.3 & 62.4 & 60.8 & 60.2 & 77.0 & 63.0 & 65.4 & 81.4 & 63.9 & 64.1 & 66.4 & 92.0 & 77.8 & 87.5 & 91.7 \\
\hline
\end{tabular}

Note: 1 . Tholeiite with $<0.85 \% \mathrm{TiO}_{2}$, average of 20 analyses. 2 . Tholeiite with 0.85 to $1.0 \% \mathrm{TiO}_{2}$, average of 16 analyses. 3 . Tholeiite with 1.0 to $1.2 \%$ TiO , average of 77 analyses, 4 . Tholeiite with $>1.2 \% \mathrm{TiO}_{2}$, average of 13 analyses. 5 . Plagioclase basalt with $<0.7 \% \mathrm{TiO}_{2}$; average of 23 analyses. 6 . Plagioclase basalt with 0.7 to $0.95 \%$ TiO 2 , average of. 38 analyses. 7. Plagioclase basalt with $>0.95 \% \mathrm{TiO}_{2}$, average of 33 analyses. 8 . Low- $\mathrm{Mg}$, plagioclase basalt, altered, average of 7 analyses. 9 . Picrite, average of 5 analyses. 10. Picritic basalt, high-Ti series, average of 17 analyses. 11. Picritic basalt, low-Ti series, average of 23 analyses. 12. Peridotite, average of 3 analyses. 13. Gabbro, average of 3 analyses. 14. Eucrite, average of 3 analyses. 15. Eucrite, melanocratic, average of 4 analyses. 


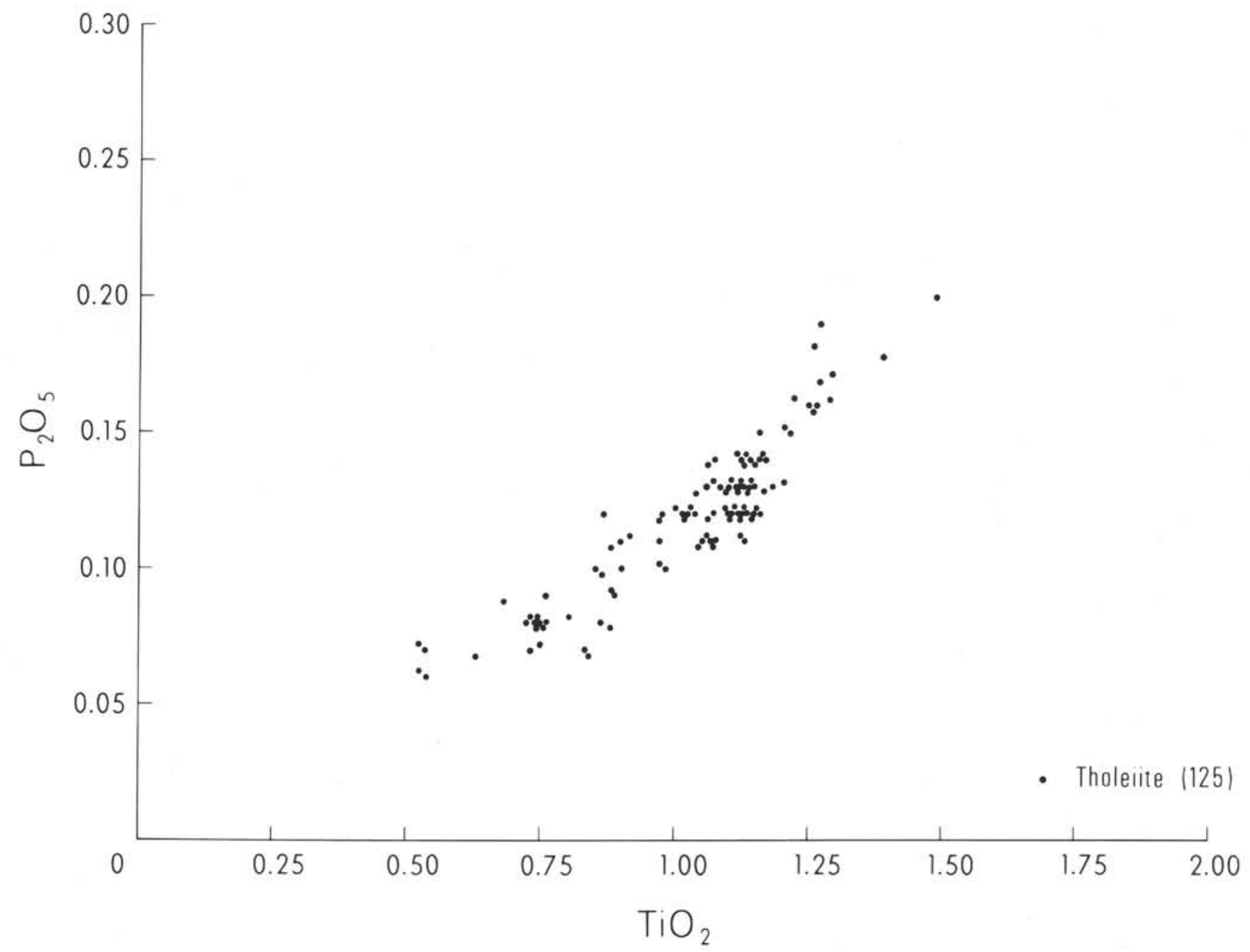

Figure 2. $\mathrm{P}_{2} \mathrm{O}_{5}-\mathrm{TiO}_{2}$ diagram for 125 analyses of undifferentiated tholeiite.

from the study of similar rocks from the tholeiitic oceanic islands. A Sr content of about $155 \mathrm{ppm}$ is inferred from the variation diagrams for the phenocryst feldspars of bulk bytownite composition of this group.

\section{Picrites and Picritic Basalts}

Thirty-five or $15 \%$ of the analyzed samples (plus 10 repeats) are termed picrites and picritic basalts. As in the case of the plagioclase basalts, these too can be separated into low- $\mathrm{Ti}$ and high- $\mathrm{Ti}$ series although overlap of the subparallel trends (e.g., in the $\mathrm{TiO}_{2}$ $\mathrm{Al}_{2} \mathrm{O}_{3}$ diagram, Figure 3) does not permit a clear separation simply on $\mathrm{TiO}_{2}$ values. The two picritic series are again separated on the $\mathrm{TiO}_{2}-\mathrm{MgO}$ diagram (Figure 4). The two subseries cannot be separated on the $2 \mathrm{Fe}_{2} \mathrm{O}_{3}-\mathrm{MgO}$ diagram (Figure 1) where they trend away from the field of undifferentiated tholeiite and from $10.5 \% \quad \Sigma \mathrm{Fe}_{2} \mathrm{O}_{3}$. On the $\mathrm{Al}_{2} \mathrm{O}_{3}-\mathrm{MgO}$ diagram (Figure 5) all of the picritic series form a single trend away from the field of undifferentiated tholeiites towards $50 \% \mathrm{MgO}$. The series is therefore accounted for by the accumulation of an olivine with a bulk composition of $10.5 \% \quad \Sigma \mathrm{Fe}_{2} \mathrm{O}_{3}$ and $50 \% \quad \mathrm{MgO}$ or chrysolite. Figure 5 is of particular interest as it illustrates that simple fractionation processes do indeed operate within the oceanic ridge basalts. The two best represented series are due to the accumulation of bytownite and chrysolite, respectively, whereas the low$\mathrm{Mg}$, plagioclase basalts appear at first sight to form a small residual series probably due to the removal of both plagioclase and olivine which occur as a phenocryst assemblage in some of the basalts. The high $\mathrm{Ni}$ content of the low-Mg rocks shows that olivine has not been lost, and the complete alteration of the pyroxenes suggests that $\mathrm{Mg}$ was lost during secondary mineral reconstitution. The separation of the picrites and picritic basalts into two subseries is again accounted for by differences in $\mathrm{TiO}_{2}$ content of their primary melts prior to fractionation. Similarly, the $\mathrm{TiO}_{2}-\mathrm{P}_{2} \mathrm{O}_{5}$ covariance is again found here. As a further illustration of the effects of olivine fractionation of tholeiites of varied primary composition, Figure 6 has been constructed using data from MacDonald (1968), Murata and Richter (1966), Wright (1971), and Clarke (1970). A number of series of picritic basalts and picrite is seen, each resulting from the accumulation of a forsteritic olivine from primary tholeiitic basalts of different initial $\mathrm{TiO}_{2}$ content. 


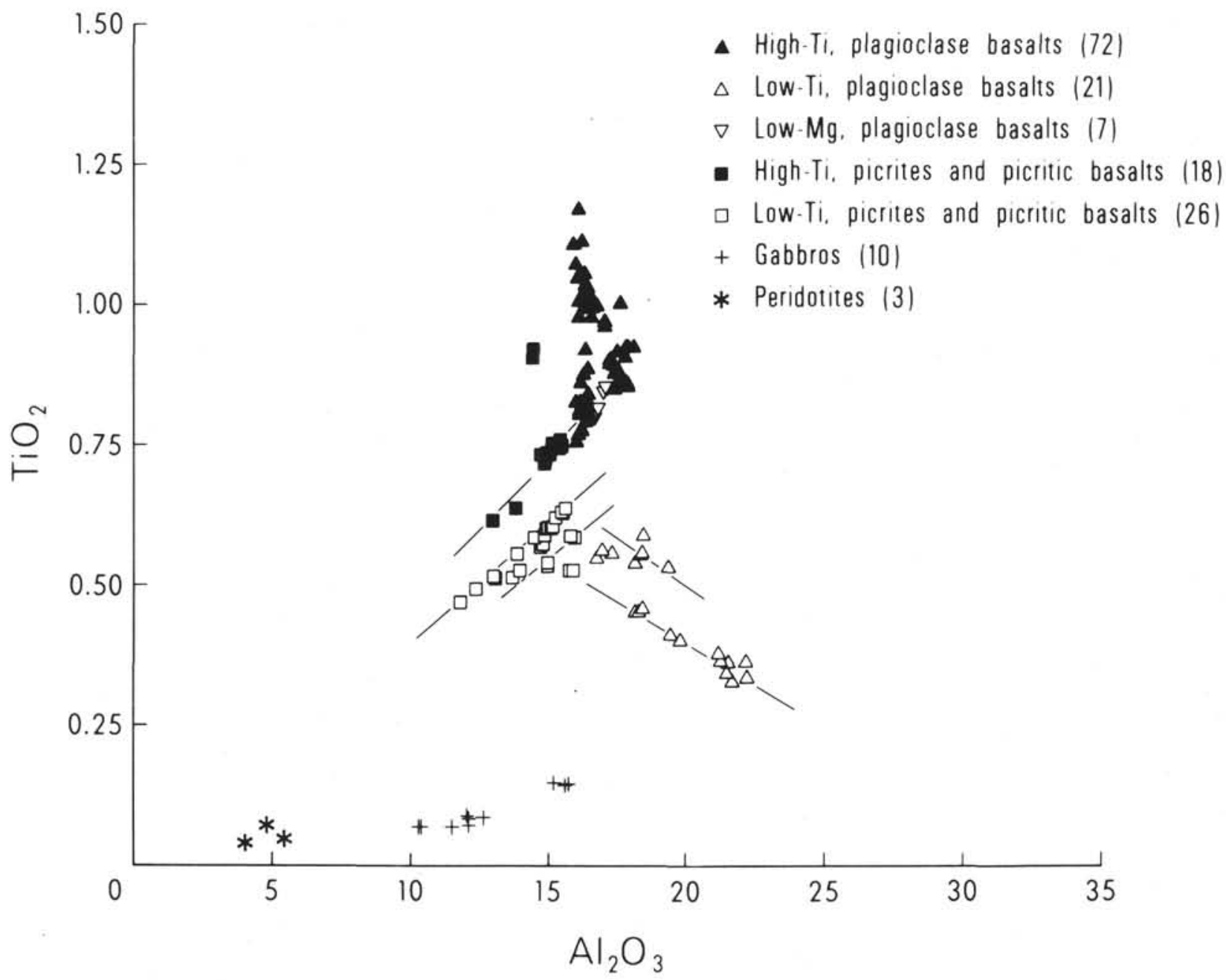

Figure 3. $\mathrm{TiO}_{2}-\mathrm{Al}_{2} \mathrm{O}_{3}$ diagram for 144 fractionated basalts and 13 gabbro-peridotites.

\section{Peridotites, Gabbros, and Eucrites}

Three peridotites and seven gabbroic rocks were analyzed, three of the latter in duplicate. The serpentinized peridotites plot on the extension of the picrite series trend in some diagrams (Figures 1 and 3), suggesting that the olivine has a bulk composition of chrysolite and that the peridotites could have formed by the accumulation of olivine from tholeiite. An average of the three analyzed samples is listed in Table 4 along with four averages of the gabbros. The gabbros show an increase in $\mathrm{MgO}$ and $\mathrm{Ni}$ and a decrease in $\mathrm{Al}_{2} \mathrm{O}_{3}, \mathrm{CaO}$, and $\mathrm{Na}_{2} \mathrm{O}$ with increasing depth, indicating an increase in olivine and orthopyroxene with depth. The uppermost analyzed gabbro (15\% $\mathrm{Al}_{2} \mathrm{O}_{3}, 8 \% \Sigma \mathrm{Fe}_{2} \mathrm{O}_{3}, 10 \% \mathrm{MgO}$, and $14 \% \mathrm{CaO}$ ) resembles the average rock analysis (plag.-ol.-augite cumulate) of Lower Zone b of the Skaergaard Intrusion (Wager and Brown, 1968, tab. 5, p. 152), whereas the other eucritic gabbros differ from the Skaergaard cumulates in having lower iron and higher $\mathrm{CaO}$ and $\mathrm{MgO}$ contents. The oceanic eucrites must contain a more forsteritic olivine and a more calcic plagioclase than do corresponding rocks exposed in the Skaergaard Intrusion. Further comparison with the eucritic layered rocks of Rhum (Wager and Brown, 1968, tab. 21, p. 285 ) shows that although the $\mathrm{MgO}$ contents are similar, the oceanic eucrites are more calcic.

The oceanic eucrites have the same $\mathrm{Mg} / \mathrm{Fe}$ ratio as the peridotites, so that the eucrites cannot represent a liquid from which olivine crystallized to form the cumulates now represented by the serpentinized peridotites. The composition is, however, close to that predicted for an accumulation of diopsidic augite, magnesian orthopyroxene, olivine, and calcic plagioclase with loss of much of the interstitial liquid.

The less magnesian gabbros, which are finer grained, are probably close to the parental magma for this group. Our preferred interpretation of these unusual rocks is that they are a rhythmically layered series. However, though coarse chromite is present, no chromite layers were recovered from the drill core. The mineralogical similarities, e.g., the well-developed exsolution lamellae of the pyroxenes in gabbros, eucrites, and peridotites suggests that these rocks belong to a single related unit.

\section{Trace Element Relationships}

The lack of alteration in many of the samples is reflected in the unusually distinct $\mathrm{K} / \mathrm{Rb}$ and $\mathrm{K} / \mathrm{Ba}$ 


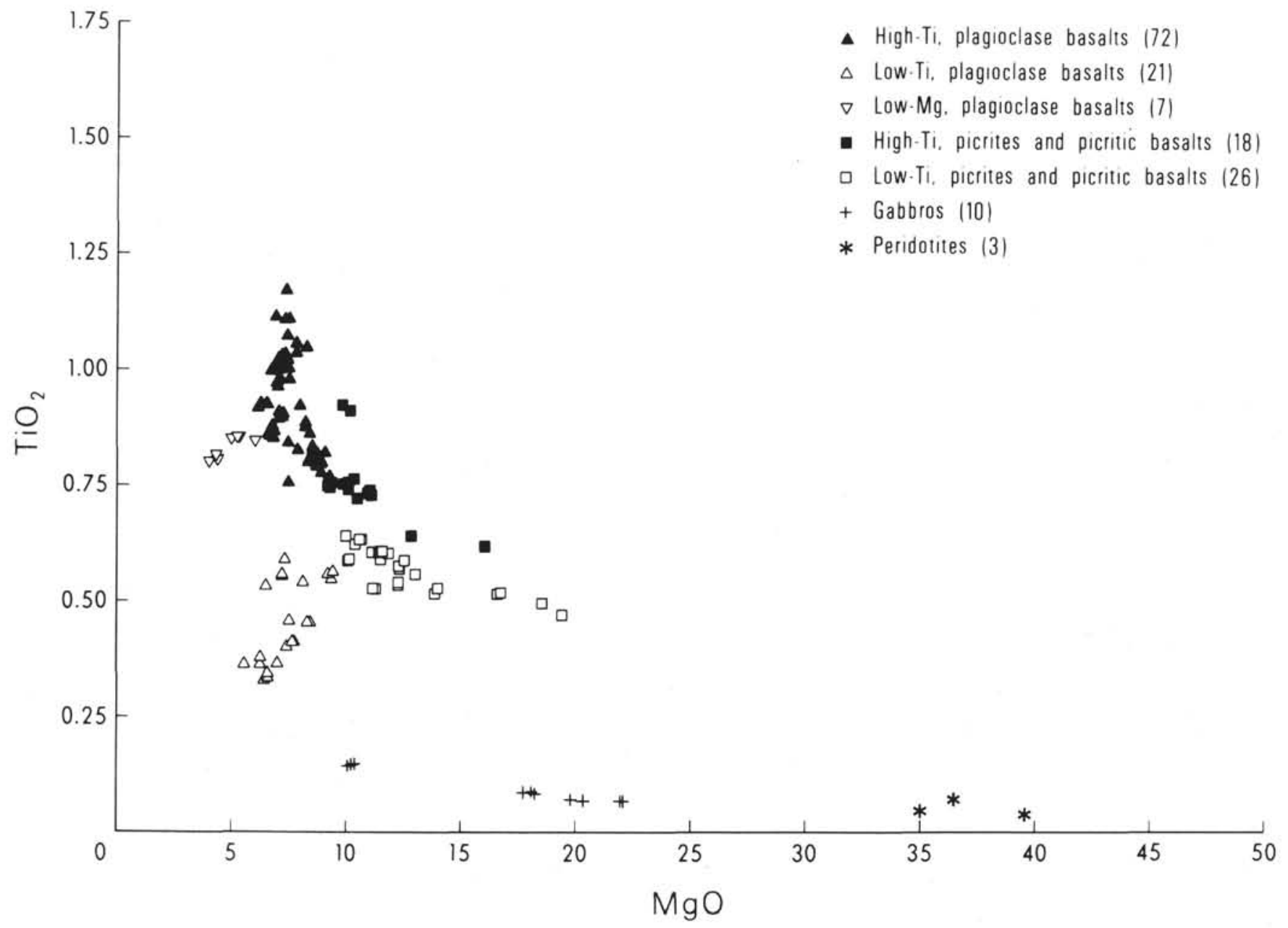

Figure 4. $\mathrm{TiO}_{2}-\mathrm{MgO}$ diagram for 144 fractionated basalts and 13 gabbro-peridotites.

relationships. Thus Site 334 has a K/Rb ratio of 453 with a correlation coefficient of 0.98 and no points except for one eucrite lie outside the statistical uncertainty of the X-ray counts accumulated. The ratio is constant, a point of some interest in view of the many claims for $\mathrm{K} / \mathrm{Rb}$ values of 1200 or more which exist in the literature for other oceanic rocks. Hole 333A has an average $\mathrm{K} / \mathrm{Rb}$ ratio of 490 but four samples have a $\mathrm{K} / \mathrm{Rb}$ ratio of 340 and three high-K samples have ratios of 710 . Illite preferentially absorbs $\mathrm{Rb}$ over $\mathrm{K}$, and it is likely that some other diagenetic phase, e.g., phillipsite, preferentially incorporates $\mathrm{K}$. Hole $332 \mathrm{~A}$ has a K/Rb ratio of 460 with $r=0.96$, but Site 335though with an average $\mathrm{K} / \mathrm{Rb}$ ratio of 480 -includes some $\mathrm{Rb}$-enriched samples which are thought on other grounds to be altered rocks. Hole 332B also includes several $\mathrm{K}$-enriched samples with ratios over 800 . It seems that the whole series may have had a constant $\mathrm{K} / \mathrm{Rb}$ near $450-480$, and that diffraction study will reveal the presence of secondary potassic phases in the rocks which depart from this range.

$\mathrm{Ba}$ decreases in amount much less than does $\mathrm{K}$, there still being at least $40 \mathrm{ppm}$ in rocks of less than $0.05 \% \mathrm{~K}$. $\mathrm{Ba}$ apparently has a higher partition coefficient than either $\mathrm{K}$ or $\mathrm{Rb}$ in calcic plagioclase. The range is from $40 \mathrm{ppm}$ in the eucrites to an average of $80 \mathrm{ppm}$ in the tholeiitic basalts.
$\mathrm{Sr}$ has a rather complex distribution, being very low $(10 \mathrm{ppm})$ in the eucrites but increasing rapidly in the more "alkaline" tholeiites from 70 to 90 to a maximum of $150 \mathrm{ppm}$. The plagioclase fractionated series has a range from 70 to $120 \mathrm{ppm}$, increasing with feldspar content. Thus $\mathrm{Sr}$ increases both with plagioclase content and with alkalinity.

$\mathrm{Ni}$ is of course mainly dominated by the olivine content of the rocks, the slope of the $\mathrm{Mg} / \mathrm{Ni}$ distribution being similar not only to the picrites of the 1959 Kilauea lavas but also to Archaean metapicrite series. The eucrite gabbros have lower $\mathrm{Ni}$ relative to $\mathrm{Mg}$ due to the presence of large amounts of pyroxene. The bulk of the tholeiites have from 80 to $120 \mathrm{ppm}$, with olivine cumulates exceeding $900 \mathrm{ppm}$. Surprisingly the low-Mg, plagioclase basalts have between 129 and 155 ppm $\mathrm{Ni}$, indicating that they may in fact be residues after pyroxene fractionation rather than olivine. Other than the eucrites of Site 334, none of the Leg 37 rocks shows evidence of pyroxene fractionation.

\section{GEOCHEMICAL STRATIGRAPHY}

Each hole is considered separately and some stratigraphic correlation established between Holes 332A and 332B, based on chemical similarity . Such a stratigraphic approach to the geochemistry cannot be so 


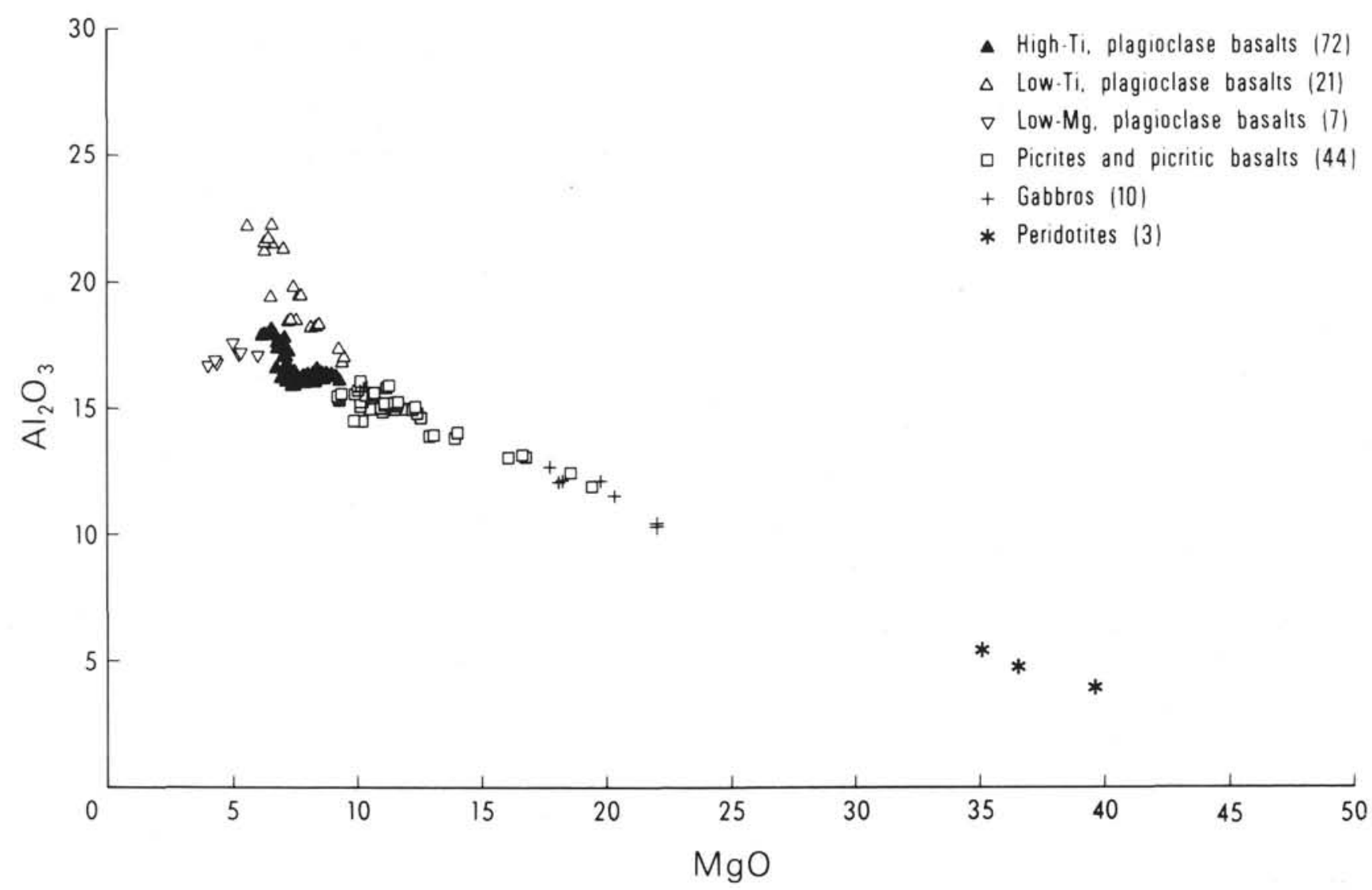

Figure 5. $\mathrm{Al}_{2} \mathrm{O}_{3}-\mathrm{MgO}$ diagram for 144 fractionated basalts.

readily achieved by mixing analyses from different laboratories due to interlaboratory analytical variation.

\section{Hole 332B}

The major element analyses are listed together with their depths in meters below the sea bed in Table 10B, Chapter 2 (this volume). The shipboard summary divides the igneous section into 11 lithologic units and 45 subunits based on lithologic and petrographic variations or cooling breaks in the sequence. No samples were available to us from Subunits 17, 21, 24, $26,28,29,30,32,34,37,39,40,42$, and 43 . The remainder of the core can be subdivided into 43 chemical subunits. Of the 29 boundaries separating the petrographic subunits identified in the shipboard summary, only 16 correspond with the chemical boundaries established here. At least 13 of the textural variations noted in the shipboard summary do not correspond with any significant chemical variation.

All of the cores except petrographic Subunit 7 are reported as probable flows, while the latter is a probable dolerite intrusion. The chemical subdivision established here, however, shows 7 to be a composite of 4 units of plagioclase and tholeiite basalt. Although most dikes and sills have margins lacking phenocrysts due to the eccentric rotation of phenocrysts by shearing caused by wall friction (Bhattacharji, 1967), there is no symmetric arrangement of the tholeiite zones for Subunit 7 , so that it is improbable that it is only a single intrusion.
The overall broad chemical pattern of repeated picritic series with plagioclase basalts and interspersed, sparsely phyric or aphyric tholeiites was established in the shipboard summary. The finer chemical grouping established here allows the subdivision of these broader groups. Thus the uppermost units of plagioclase basalts identified as Lithologic Units 1 and 3 and chemical units $a$ and $d$ in the shipboard summary, are here further subdivided into 13 chemical subunits. Similarly the olivine phyric to highly olivine phyric basalts of Unit 4 (shipboard chemical unit $e$ ) is here divided into 6 subunits of picrite and picritic basalt (Table 4).

The vertical profiles (oxide or element versus depth, Figure 7) strongly suggest a cyclic alternation of magma type with at least 10 cycles of low $\mathrm{Si}, \mathrm{Ti}, \mathrm{Fe}, \mathrm{Ca}$, $\mathrm{K}, \mathrm{P}, \mathrm{Rb}, \mathrm{Sr}$ coinciding with high- $\mathrm{Mg}$ and olivine or high plagioclase contents. These cycles are not confined to the two main picrite-picritic basalt regions only, but also occur in the upper plagioclase basalts. In this latter case a high-alumina content correlates with the low $\mathrm{Si}$, $\mathrm{Ti}, \mathrm{Fe}$, etc. Thus the cyclical differences are not constant throughout, as in the picritic series $\mathrm{Al}, \mathrm{Si}, \mathrm{Ti}, \mathrm{Fe}$, etc show positive correlation, but in the plagioclase cumulates Al correlates negatively with these elements.

The rhythmic variations in all elements makes delimiting flow boundaries difficult. Thus in Hole 332B between 385 and 470 meters there is a distinctive series of picritic basalts and picrites with a general increase in $\mathrm{MgO}$ and decrease in $\mathrm{SiO}_{2}, \mathrm{Al}_{2} \mathrm{O}_{3}, \mathrm{TiO}_{2}$, etc downward. This unit could be either a differentiated sill or a pillow- 


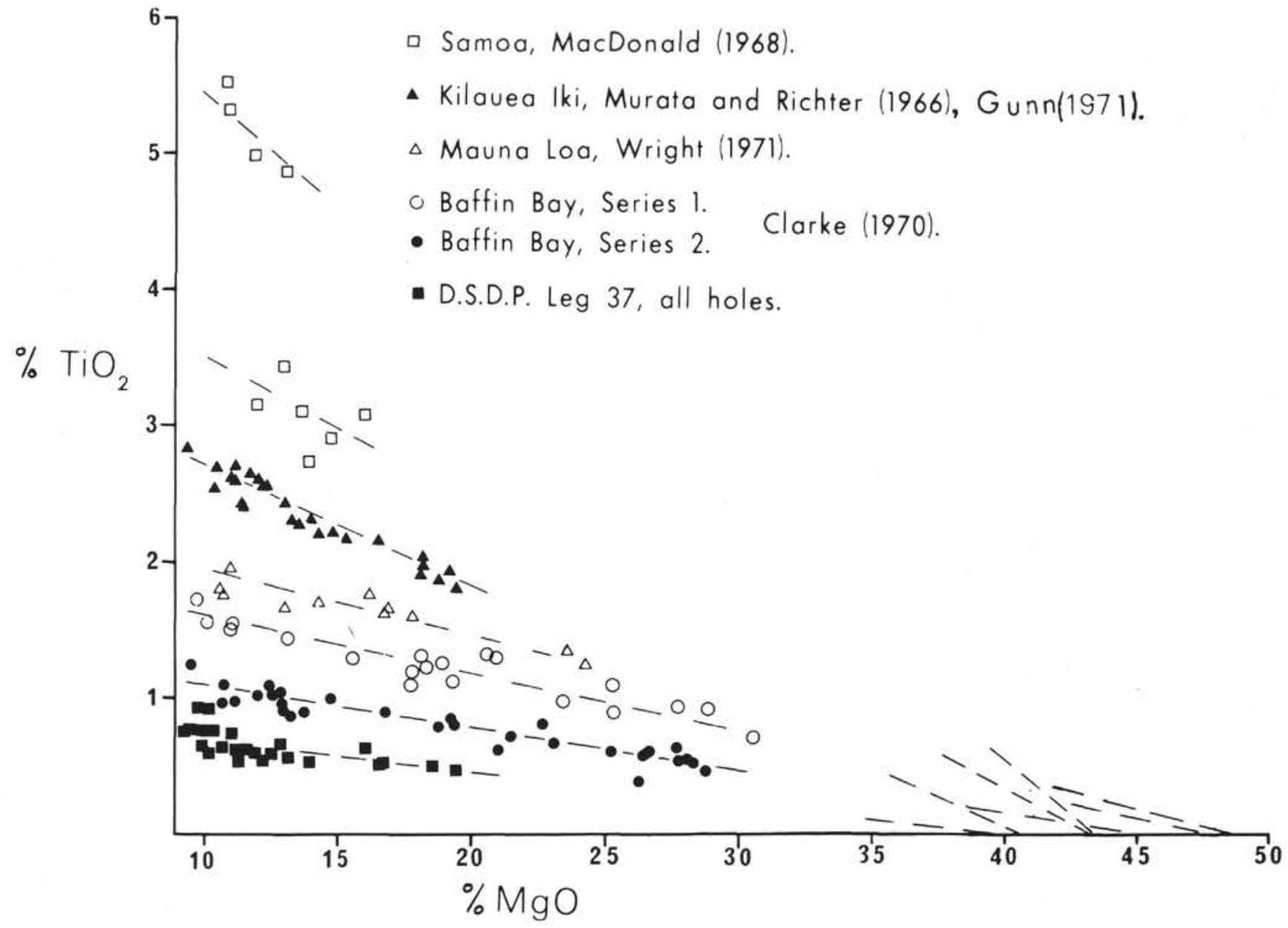

Figure 6. $\mathrm{TiO}_{2}-\mathrm{MgO}$ diagram for picritic series from Samoa, Hawaii, Baffin Bay, and Leg 37 .

pile of decreasing olivine content with time or a series of variable, gravity stratified, sills or flows.

This hole therefore includes a complex array of undifferentiated tholeiitic basalts passing into rhythmically stratified high-alumina variants, plagioclase cumulative series, and olivine cumulative series. Olivine or pyroxene-depleted residual rocks are included although we have not been able to identify plagioclase-depleted rocks.

\section{Hole 332A}

The shipboard summary lists seven lithologic units from which we have samples of all except Unit 2 (Cores 6-2 to 7-1). Partial major element analyses of 49 samples are listed in the shipboard summary, where the stratigraphic section was divided into seven broad chemical units lettered "a" to "g." Forty-one of the partially analyzed samples were further subdivided into eight lava groups identified by the letters $\mathrm{A}$ to $\mathrm{H}$ and average compositions calculated for the lava types (shipboard summary). Although we have only half the present number of samples analyzed (Table 8B, Chapter 2, this report), we have established 11 chemical units. There is a good correlation between the shipboard lava groups $\mathrm{A}$ to $\mathrm{H}$ and the terminology used in this report. Shipboard group A equates with the low-
$\mathrm{Ti}$, plagioclase basalt, group $\mathrm{G}$ with the high-Ti, plagioclase basalts, group $\mathrm{H}$ with the picrite basalt, while groups $\mathrm{B}, \mathrm{C}, \mathrm{D}, \mathrm{E}$, and $\mathrm{F}$ are tholeiites corresponding to our types $3,2,3,3$, and 4 , respectively.

The chemical range for some elements between the picritic and feldspathic members is extreme with $\mathrm{TiO}_{2}$ having a range of $0.36 \%$ to $1.2 \%$ and $\mathrm{K}_{2} \mathrm{O}$ from $0.10 \%$ to $0.47 \%$. The average compositions of the 11 units established here, together with their C.I.P.W. norms is listed in Table 5. The profiles for oxide and element versus depth is shown in Figure 8.

\section{Correlation of Holes 332A and 332B}

Because these holes were drilled only 107 meters apart, some stratigraphic correlation could be expected. The shipboard summary tentatively correlates 332B, chemical group $d$ with $332 \mathrm{~A}$, chemical group $\mathrm{f}$. Based on this, further correlation of $332 \mathrm{~A}(\mathrm{e})$ with $332 \mathrm{~B}(\mathrm{c})$ was suggested. As we have established a finer division of the chemical stratigraphy we are able to improve this correlation. The main shipboard correlation between the plagioclase basalts of $332 \mathrm{~B}(\mathrm{~d})$ and $332 \mathrm{~A}(\mathrm{f})$ is not borne out by our analyses. 332B(d) has been subdivided by us into seven subunits of high-Ti, plagioclase basalt and type 3 undifferentiated tholeiite $(1.0 \%$ to $1.2 \%$ $\mathrm{TiO}_{2}$ ), whereas $332 \mathrm{~A}(\mathrm{f})$ is subdivided into an upper unit 
TABLE 4

Average Compositions for Montreal Chemical Groups of Holes 332B, and 332D

\begin{tabular}{lcccccccccccc}
\hline & 1 & 2 & 3 & 4 & 5 & 6 & 7 & 8 & 9 & 10 & 11 \\
\hline $\mathrm{SiO}_{2}$ & 48.53 & 45.92 & 49.41 & 48.83 & 49.20 & 49.43 & 50.58 & 49.97 & 50.09 & 50.14 & 48.25 & 50.64 \\
$\mathrm{~A}_{2} \mathrm{O}_{3}$ & 22.21 & 24.04 & 18.48 & 21.67 & 19.58 & 18.26 & 14.70 & 16.55 & 15.82 & 16.59 & 15.23 & 16.39 \\
$\mathrm{TiO}_{2}$ & 0.341 & 0.241 & 0.458 & 0.347 & 0.407 & 0.453 & 1.071 & 1.013 & 1.036 & 0.990 & 1.065 & 1.021 \\
$\mathrm{Fe}_{2} \mathrm{O}_{3}$ & 5.38 & 4.94 & 6.76 & 5.49 & 6.55 & 7.29 & 11.25 & 9.61 & 10.09 & 9.63 & 10.32 & 9.49 \\
$\mathrm{MnO}$ & 0.088 & 0.102 & 0.118 & 1.090 & 0.106 & 0.122 & 0.183 & 0.151 & 0.155 & 0.148 & 0.172 & 0.135 \\
$\mathrm{MgO}$ & 6.21 & 4.23 & 7.55 & 6.50 & 7.64 & 8.43 & 7.32 & 7.11 & 7.26 & 7.12 & 7.25 & 7.40 \\
$\mathrm{CaO}$ & 15.72 & 18.81 & 15.54 & 15.54 & 14.98 & 14.44 & 12.28 & 13.29 & 13.11 & 13.06 & 15.32 & 12.62 \\
$\mathrm{Na} 2 \mathrm{O}$ & 1.43 & 1.45 & 1.54 & 1.46 & 1.45 & 1.49 & 2.20 & 1.98 & 2.08 & 1.99 & 2.01 & 2.03 \\
$\mathrm{~K}_{2} \mathrm{O}$ & 0.053 & 0.201 & 0.101 & 0.043 & 0.052 & 0.039 & 0.308 & 0.198 & 0.226 & 0.208 & 0.245 & 0.140 \\
$\mathrm{P}_{2} \mathrm{O}_{5}$ & 0.04 & 0.06 & 0.05 & 0.04 & 0.05 & 0.12 & 0.12 & 0.12 & 0.12 & 0.12 & 0.14 & 0.12 \\
$\mathrm{Total}$ & 100.002 & 99.994 & 100.007 & 100.010 & 100.005 & 100.004 & 100.012 & 99.992 & 99.987 & 99.996 & 100.002 & 99.986 \\
$\mathrm{Ni}$ & 95.9 & 75.0 & 129.9 & 96.4 & 105.0 & 121.4 & 55.6 & 86.3 & 90.2 & 79.0 & 74.0 & 74.5 \\
$\mathrm{Rb}$ & 1.1 & 3.9 & 3.1 & .7 & 1.0 & .1 & 5.6 & 3.2 & 2.8 & 3.6 & 6.1 & 2.3 \\
$\mathrm{Sr}$ & 97.5 & 122.5 & 95.3 & 95.2 & 86.0 & 79.7 & 117.3 & 113.7 & 118.3 & 118.3 & 147.8 & 110.3 \\
$\mathrm{Ba}$ & 43.6 & 47.5 & 39.1 & 47.8 & 39.4 & 39.9 & 69.4 & 85.9 & 120.2 & 70.0 & 57.0 & 68.6
\end{tabular}

CIPW Norms

\begin{tabular}{|c|c|c|c|c|c|c|c|c|c|c|c|c|}
\hline Qz & 0.00 & 0.00 & 0.00 & 0.16 & 0.21 & 0.16 & 1.71 & 1.42 & 1.15 & 1.69 & 0.00 & 2.49 \\
\hline Or & 0.31 & 1.19 & 0.60 & 0.25 & 0.31 & 0.23 & 1.82 & 1.17 & 1.34 & 1.23 & 1.45 & .83 \\
\hline Plag. & 66.13 & 62.07 & 56.25 & 64.81 & 59.04 & 55.63 & 47.94 & 52.44 & 50.77 & 52.56 & 48.82 & 52.38 \\
\hline $\mathrm{Ne}$ & 0.00 & 4.71 & 0.00 & 0.00 & 0.00 & 0.00 & 0.00 & 0.00 & 0.00 & 0.00 & 0.00 & 0.00 \\
\hline Di & 19.01 & 27.85 & 26.93 & 19.55 & 21.89 & 22.70 & 25.09 & 23.89 & 25.24 & 22.95 & 35.14 & 21.57 \\
\hline Hy & 11.31 & 0.00 & 12.18 & 12.09 & 14.83 & 17.13 & 16.23 & 14.68 & 14.86 & 15.21 & 1.19 & 16.38 \\
\hline O1 & 0.15 & 1.42 & 0.11 & 0.00 & 0.00 & 0.00 & 0.00 & 0.00 & 0.00 & 0.00 & 6.57 & 0.00 \\
\hline Mt & 1.95 & 1.79 & 2.45 & 1.99 & 2.37 & 2.64 & 4.08 & 3.48 & 3.66 & 3.49 & 3.74 & 3.44 \\
\hline I1 & 0.65 & 0.46 & 0.87 & 0.66 & 0.77 & 0.86 & 2.03 & 1.92 & 1.97 & 1.88 & 2.02 & 1.94 \\
\hline Ap & 0.09 & 0.13 & 0.11 & 0.09 & 0.09 & 0.11 & 0.26 & 0.26 & 0.26 & 0.26 & 0.31 & 0.26 \\
\hline Total & 99.60 & 99.62 & 99.50 & 99.60 & 99.51 & 99.46 & 99.17 & 99.27 & 99.23 & 99.27 & 99.23 & 99.27 \\
\hline An $\%$ & 80.8 & 93.9 & 75.8 & 80.0 & 78.2 & 76.3 & 59.8 & 66.8 & 64.0 & 66.7 & 63.8 & 65.9 \\
\hline
\end{tabular}

Note: 1. Low-Ti, plagioclase basalts, average of 3 analyses. 2. Low-Ti, plagioclase basalt, 1 analysis. 3. Low-Ti, plagioclase basalt, 1 analysis. 4. Low-Ti, plagioclase basalt, average of 4 analyses. 5. Low-Ti, plagioclase basalt, average of 3 analyses. 6. Low-Ti, plagioclase basalt, average of 2 analyses. 7. Type-3, tholeiite, average of 2 analyses. 8. High-Ti, plagioclase basalt, average of 8 analyses. 9 . Type-3 tholeiite, average of 3 analyses. 10. High-Ti, plagioclase basalt, average of 7 analy ses. 11 . Type- 3 tholeiite, 1 analysis. 12. High-Ti, plagioclase basalt, average of 4 analyses. 13. Type-3 tholeiite, 1 analysis. 14. High-Ti, plagioclase basalt, average of 7 analyses. 15. Density stratified, high-Ti, picritic basalt to picrite body, average of 4 analy ses. 16. High-Ti, picritic basalt, average of 11 analyses. 17. Low-Ti, picritic basalt, average of 4 analyses. 18. Picrite, 1 analysis. 19. Low-Ti, picritic basalt, average of 4 analyses. 20. Picrite, average of 2 analyses. 21 . High-Ti, plagioclase basalt, average of 4 analyses. 22. Type-3 tholeiite, 1 analysis. 23. High-Ti, plagioclase basalt, average of 13 analyses. 24 . Type-3 tholeiite, 1 analysis. 25. High-Ti, plagioclase basalt, average of 7 analyses. 26 . Type- 3 tholeiite, average of 2 analyses. 27 . Type-1 tholeiite, 1 analysis. 28. Type-2 tholeiite, 1 analysis. 29. Type-3 tholeiite, average of 3 analyses. 30 . High-Ti, plagioclase basalt, average of 3 analyses. 31. Low-Ti, plagioclase basalt, average of 3 analyses. 32. Type- 3 tholeiite, average of 2 analyses. 33 . Type-2 tholeiite, 1 analysis. 34 . Type-1 tholeiite, 1 analysis. 35. Low-Ti, picritic basalt, average of 2 analyses. 36. Picrite, 1 analysis. 37. Low-Ti, picritic basalt, average of 2 analyses. 38, Low-Ti, plagioclase basalt, average of 5 analyses. 39. High-Ti, plagioclase basalt, average of 9 analyses. 40 . Low-Ti, picritic basalt, average of 4 analyses. 41 . High-Ti, plagioclase basalt, average of 7 analy ses. 42 . Type- 3 tholeiite, average of 8 analyses. 43 . High-Ti, picritic basalt, 1 analysis. D.1. Hole 332D Type-3 tholeiite, one analysis.

of type 4 tholeiite (more than $1.2 \% \mathrm{TiO}_{2}$ ) and a lower unit of high-Ti, plagioclase basalt. The separation of the high and low-Ti plagioclase basalts (Figures 1, 3, 4) does not permit this correlation. However, both holes contain two horizons of low-Ti, plagioclase basalts, in each case one horizon occurs near the top of the acoustic basement while the other is near the bottom limit of the hole. A chemical correlation is suggested between the uppermost low-Ti, plagioclase basalts of the two holes, being in shipboard terminology $332 \mathrm{~A}$ (a) with $332 \mathrm{~B}(\mathrm{a})$. However, these latter two units have opposing directions of remnant magnetism, and cannot be the same stratigraphic unit. The low-Ti plagioclase basalts have been separated into two subparallel series (Figure 3). In terms of this separation both groups of correlated data fall into the lowest-Ti subseries. The low- $\mathrm{Ti}$, plagioclase basalts near the bottoms of Holes $332 \mathrm{~A}$ and $332 \mathrm{~B}$ can be identified in shipboard terms as belonging to groups $332 \mathrm{~A}(\mathrm{~g})$ and $332 \mathrm{~B}(\mathrm{i})$. It is tempting to see a correlation in this pair also, as the units from both holes comprise the Ti-rich subseries of the low-Ti, plagioclase basalts (Figure 3). However, in terms of the 
TABLE 4 - Continued

\begin{tabular}{|c|c|c|c|c|c|c|c|c|c|c|c|c|}
\hline & 13 & 14 & 15 & 16 & 17 & 18 & 19 & 20 & 21 & 22 & 23 & 24 \\
\hline $\mathrm{SiO}_{2}$ & 51.28 & 50.48 & 48.05 & 48.68 & 48.43 & 46.71 & 47.84 & 47.29 & 47.51 & 49.40 & 47.92 & 50.93 \\
\hline $\mathrm{A}_{2} \mathrm{O}_{3}$ & 15.60 & 16.30 & 14.53 & 15.20 & 15.09 & 12.44 & 15.56 & 13.12 & 16.44 & 14.78 & 16.65 & 14.47 \\
\hline $\mathrm{TiO}_{2}$ & 1.124 & 0.992 & 0.704 & 0.742 & 0.602 & 0.495 & 0.597 & 0.517 & 0.807 & 1.125 & 0.831 & 1.209 \\
\hline $\mathrm{Fe}_{2} \mathrm{O}_{3}$ & 9.34 & 9.58 & 10.60 & 10.57 & 10.29 & 10.36 & 10.52 & 10.40 & 10.63 & 10.43 & 10.78 & 11.75 \\
\hline $\mathrm{MnO}$ & 0.145 & 0.148 & 0.157 & 0.143 & 0.136 & 0.151 & 0.146 & 0.143 & 0.156 & 0.173 & 0.156 & 0.183 \\
\hline $\mathrm{MgO}$ & 7.63 & 7.42 & 12.50 & 10.29 & 11.59 & 18.60 & 10.88 & 16.74 & 7.68 & 7.69 & 7.01 & 6.86 \\
\hline $\mathrm{CaO}$ & 12.45 & 12.77 & 11.64 & 12.03 & 11.65 & 9.51 & 12.22 & 9.87 & 14.03 & 13.92 & 13.90 & 11.82 \\
\hline $\mathrm{Na}_{2} \mathrm{O}$ & 2.10 & 2.01 & 1.57 & 2.07 & 2.00 & 1.56 & 2.00 & 1.70 & 2.40 & 2.09 & 2.40 & 2.29 \\
\hline $\mathrm{K}_{2} \mathrm{O}$ & 0.199 & 0.198 & 0.157 & 0.198 & 0.143 & 0.127 & 0.183 & 0.169 & 0.261 & 0.264 & 0.270 & 0.366 \\
\hline $\mathrm{P}_{2} \mathrm{O}_{5}$ & 0.13 & 0.11 & 0.08 & 0.08 & 0.06 & 0.05 & 0.07 & 0.05 & 0.09 & 0.13 & 0.10 & 0.13 \\
\hline Total & 99.998 & 100.008 & 99.988 & 100.003 & 99.991 & 100.003 & 100.016 & 99.999 & 100.004 & 100.002 & 100.017 & 100.008 \\
\hline $\mathrm{Ni}$ & 284.6 & 95.6 & 405.5 & 272.3 & 358.3 & 681.6 & 346.8 & 619.5 & 169.3 & 97.4 & 156.0 & 52.9 \\
\hline $\mathrm{Rb}$ & 4.9 & 4.4 & 1.8 & 3.6 & 1.9 & 2.5 & 3.2 & 3.5 & 2.9 & 5.4 & 3.1 & 4.8 \\
\hline $\mathrm{Sr}$ & 116.4 & 113.1 & 140.0 & 92.3 & 112.6 & 57.3 & 133.7 & 66.7 & 101.5 & 118.2 & 106.3 & 114.2 \\
\hline $\mathrm{Ba}$ & 84.7 & 64.4 & 52.8 & 49.7 & 46.4 & 55.5 & 40.5 & 48.9 & 56.9 & 78.5 & 50.8 & 81.2 \\
\hline \multicolumn{13}{|c|}{ CIPW Norms } \\
\hline Qz & 3.05 & 2.01 & 0.00 & 0.00 & 0.00 & 0.00 & 0.00 & 0.00 & 0.00 & 0.00 & 0.00 & 2.64 \\
\hline Or & 1.18 & 1.17 & 0.93 & 1.17 & 0.85 & 0.75 & 1.08 & 1.54 & 1.56 & 1.56 & 1.60 & 2.16 \\
\hline Plag & 50.32 & 51.88 & 45.42 & 49.12 & 48.70 & 39.77 & 49.86 & 42.06 & 50.55 & 47.85 & 53.31 & 47.50 \\
\hline $\mathrm{Ne}$ & 0.00 & 0.00 & 0.00 & 0.00 & 0.00 & 0.00 & 0.00 & 0.00 & 1.67 & 0.00 & 0.47 & 0.00 \\
\hline Di & 22.93 & 22.49 & 20.13 & 22.21 & 20.58 & 16.15 & 21.92 & 16.72 & 28.99 & 30.84 & 28.06 & 24.23 \\
\hline Hy & 16.01 & 16.14 ， & 16.61 & 12.00 & 11.81 & 10.18 & 7.23 & 11.26 & 0.00 & 10.93 & 0.00 & 15.75 \\
\hline $\mathrm{O} 1$ & 0.00 & 0.00 & 10.74 & 9.30 & 12.27 & 27.57 & 14.04 & 23.32 & 10.88 & 1.84 & 10.08 & 0.00 \\
\hline Mt & 3.39 & 3.47 & 3.84 & 3.83 & 3.73 & 3.76 & 3.81 & 3.77 & 3.85 & 3.78 & 3.91 & 4.26 \\
\hline I1 & 2.13 & 1.88 & 1.34 & 1.41 & 1.14 & 0.94 & 1.13 & 0.98 & 1.53 & 2.14 & 1.58 & 2.30 \\
\hline Ap & 0.28 & 0.24 & 0.17 & 0.17 & 0.13 & 0.11 & 0.15 & 0.11 & 0.20 & 0.28 & 0.22 & .28 \\
\hline Total & 99.30 & 99.29 & 99.19 & 99.21 & 99.22 & 99.23 & 99.23 & 99.22 & 99.21 & 99.22 & 99.21 & 99.13 \\
\hline An $\%$ & 63.3 & 65.9 & 69.5 & 63.0 & 63.9 & 65.5 & 64.7 & 64.5 & 64.6 & 61.7 & 62.1 & 57.8 \\
\hline
\end{tabular}

fine chemical subdivisions established in the stratigraphic sequence the two differ in that the $332 \mathrm{~A}$ unit has higher $\mathrm{MgO}(1 \%$ to $2 \%)$ and lower $\mathrm{Al}_{2} \mathrm{O}_{3}(2 \%)$, $\mathrm{Fe}_{2} \mathrm{O}_{3}(1.2 \%), \mathrm{Na}_{2} \mathrm{O}(0.5 \%)$. These differences are too great to permit a positive chemical correlation.

The high- $\mathrm{Ti}$, plagioclase-olivine-pyroxene-phyric basalts at the bottom of Hole $332 \mathrm{~A}$ cannot be correlated with those of $332 \mathrm{~B}$, nor do the six tholeiite units comprising the middle part of $332 \mathrm{~A}$ correlate particularly well with those of $332 \mathrm{~B}$. This inability to clearly correlate such closely spaced holes suggests that either the lavas are erupted over extremely limited areas (which could result from a marked bottom topography) or that the main parts of the two sections are of different ages.

\section{Hole 332D}

A single analysis was made of this 6-meter core taken from the top of the lava pile when the drill bit rolled off the top of the casing of Hole 332B. The sample is a tholeiite which surprisingly is dissimilar to the one tholeiite analysis from the upper part of Hole 332A, where it overlies the upper unit of low- $\mathrm{Ti}$, plagioclase basalt. That of Hole 332D is a type 3 tholeiite with $1.173 \% \mathrm{TiO}_{2}$ while that of $332 \mathrm{~A}$ is a type 2 tholeiite with
$0.889 \% \mathrm{TiO}_{2}$. This difference further supports the possibility that the Mid-Atlantic Ridge lavas either heap up around the vents or have an extremely sinuous form when occurring as flows.

\section{Hole 333A}

Seven lithologic units were recognized in the shipboard summary. We have analyzed samples from all units except 1 . Partial analyses of 12 samples are listed in the shipboard summary and 28 new analyses were completed for this study. Alumina contents are in the range $14.5 \%$ to $16 \%$, generally increasing with depth (Figure 9) while $\mathrm{CaO}, \mathrm{K}_{2} \mathrm{O}$, and $\mathrm{Rb}$ decrease somewhat. In terms of contrasting chemistry downhole, the lavas can be grouped into 11 units of somewhat erratic composition of $7 \%-10 \% \mathrm{MgO}$ and $0.8 \%$ to $1.4 \% \mathrm{TiO}_{2}$ (Table 6). All four types of tholeiite are present in the hole, but the low-Sr subtype is absent.

Site 333 was established about $6 \mathrm{~km}$ from Site 332 within the same magnetic anomaly as the latter, but at the foot of a possible fault scarp. The aim was to obtain a deeper section from a fault scarp. It is of interest, therefore, to see whether there is any stratigraphic correlation between Sites 333 and 332, although the failure to establish a good correlation between Holes $332 \mathrm{~A}$ and 
TABLE 4 - Continued

\begin{tabular}{|c|c|c|c|c|c|c|c|c|c|c|c|}
\hline 25 & 26 & 27 & 28 & 29 & 30 & 31 & 32 & 33 & 34 & 35 & 36 \\
\hline 48.89 & 50.26 & 49.46 & 49.83 & 50.62 & 49.00 & 48.39 & 50.52 & 50.58 & 48.71 & 47.21 & 46.10 \\
\hline 16.34 & 14.74 & 15.91 & 15.79 & 15.08 & 16.68 & 14.76 & 15.06 & 14.89 & 15.73 & 13.93 & 11.91 \\
\hline 0.822 & 1.118 & 0.844 & 0.884 & 1.140 & 0.842 & 0.578 & 1.128 & 0.986 & 0.633 & 0.521 & 0.471 \\
\hline 10.56 & 11.58 & 10.73 & 10.79 & 10.83 & 10.75 & 10.14 & 10.82 & 10.46 & 10.37 & 10.17 & 10.71 \\
\hline 0.143 & 0.196 & 0.149 & 0.164 & 0.174 & 0.146 & 0.147 & 0.178 & 0.170 & 0.158 & 0.156 & 0.161 \\
\hline 8.34 & 7.11 & 8.66 & 7.84 & 7.25 & 7.35 & 12.45 & 7.14 & 7.12 & 8.64 & 14.03 & 19.48 \\
\hline 12.36 & 12.36 & 11.88 & 11.91 & 12.31 & 12.50 & 11.35 & 12.57 & 13.28 & 13.33 & 11.94 & 9.25 \\
\hline 2.34 & 2.08 & 2.08 & 2.52 & 2.18 & 2.44 & 1.95 & 2.10 & 2.22 & 2.18 & 1.82 & 1.69 \\
\hline 0.130 & 0.434 & 0.105 & 0.191 & 0.280 & 0.191 & 0.177 & 0.334 & 0.200 & 0.179 & 0.196 & 0.182 \\
\hline 0.08 & 0.12 & 0.07 & 0.08 & 0.13 & 0.09 & 0.06 & 0.13 & 0.10 & 0.07 & 0.06 & 0.05 \\
\hline 100.005 & 99.998 & 99.998 & 99.999 & 99.994 & 99.989 & 100.002 & 99.980 & 100.000 & 100.000 & 100.033 & 100.004 \\
\hline 173.3 & 161.6 & 161.5 & 140.4 & 125.4 & 72.6 & 411.5 & 92.5 & 80.8 & 282.1 & 526.2 & 798.5 \\
\hline 1.6 & 2.6 & 1.5 & 5.2 & 3.9 & 7.9 & 3.1 & 5.5 & 2.7 & 3.8 & 2.5 & 2.5 \\
\hline 89.7 & 92.4 & 80.6 & 94.1 & 106.3 & 111.0 & 76.2 & 121.0 & 127.5 & 113.9 & 101.9 & 73.0 \\
\hline 47.6 & 66.3 & 32.6 & 38.1 & 102.6 & 82.5 & 76.1 & 74.2 & 60.7 & 50.3 & 38.4 & 33.6 \\
\hline \multicolumn{12}{|c|}{ CIPW Norms } \\
\hline 0.00 & 1.65 & 0.00 & 0.00 & 2.06 & 0.00 & 0.00 & 2.06 & 1.37 & 0.00 & 0.00 & 0.00 \\
\hline 0.77 & 2.57 & .62 & 1.13 & 1.65 & 1.13 & 1.05 & 1.97 & 1.18 & 1.06 & 1.16 & 1.08 \\
\hline 53.50 & 47.20 & 51.81 & 52.53 & 48.98 & 54.65 & 47.50 & 48.45 & 48.86 & 51.06 & 44.66 & 38.68 \\
\hline 0.00 & 0.00 & 0.00 & 0.00 & 0.00 & 0.00 & 0.00 & 0.00 & 0.00 & 0.00 & 0.00 & 0.00 \\
\hline 21.95 & 25.23 & 20.40 & 22.20 & 24.15 & 22.31 & 19.98 & 25.09 & 28.57 & 26.75 & 23.66 & 16.86 \\
\hline 10.78 & 15.90 & 18.23 & 14.41 & 15.96 & 9.98 & 12.01 & 15.24 & 13.35 & 6.60 & 3.25 & 4.34 \\
\hline 6.65 & 0.00 & 2.49 & 3.15 & 0.00 & 5.43 & 13.81 & 0.00 & 0.00 & 8.64 & 21.74 & 33.36 \\
\hline 3.83 & 4.20 & 3.89 & 3.91 & 3.93 & 3.90 & 3.68 & 3.92 & 3.79 & 3.76 & 3.69 & 3.88 \\
\hline 1.56 & 2.12 & 1.60 & 1.68 & 2.17 & 1.60 & 1.10 & 2.14 & 1.87 & 1.20 & 0.99 & 0.89 \\
\hline 0.17 & 0.26 & 0.15 & 0.17 & 0.28 & 0.20 & 0.13 & 0.28 & 0.22 & 0.15 & 0.13 & 0.11 \\
\hline 99.21 & 99.13 & 99.19 & 99.19 & 99.18 & 99.18 & 99.24 & 99.17 & 99.32 & 99.22 & 99.27 & 99.20 \\
\hline 61.6 & 61.3 & 62.9 & 58.0 & 60.9 & 60.8 & 63.9 & 61.9 & 60.1 & 62.5 & 64.2 & 61.6 \\
\hline
\end{tabular}

332B suggests that this is improbable. The problem is complicated by the very low core recovery at Site 333 . The tholeiite-dominated section of Hole $333 \mathrm{~A}$ is broadly similar to that of $332 \mathrm{~A}$, and the two holes are similar in that both contain tholeiite types 2,3 , and 4 , yet lack the low-Sr subtype 3. Hole 332A differs by lacking type 1. The stratigraphic sequence of the different tholeiite types is not the same for the two holes. Attempts to establish finer chemical divisions for correlation were also unsuccessful and it seems that the two holes cannot be correlated on their chemistry.

\section{Site 334}

\section{Basalts}

The 18 analyzed samples are all quartz tholeiites from two lithologic units (Table 7). The upper Unit 1, 14 meters thick, is the least magnesian (7.5\%) and has the highest $\mathrm{TiO}_{2}(0.9 \%), \mathrm{K}_{2} \mathrm{O}(0.35 \%)$, and $\mathrm{Sr}(80 \mathrm{ppm})$. Unit 2,35 meters thick, has $0.75 \% \mathrm{TiO}_{2}, 0.15 \% \mathrm{~K}_{2} \mathrm{O}$ and $70 \mathrm{ppm}$ Sr. However, four samples between 263 and 265 meters below the sea floor and between Units 1 and 2 are transitional in composition with decreasing $\mathrm{Ti}, \mathrm{Na}, \mathrm{K}$, $\mathrm{P}, \mathrm{Sr}, \mathrm{Rb}$, and increasing $\mathrm{CaO}$ (Figure 10).

\section{Coarse-grained Rocks}

It is suggested in the shipboard summary that the presence of sedimentary breccias with gabbro and peridotite clasts in a nanno-foram matrix within the coarse-grained unit may reflect surface exposure of a mélange prior to burial by later basaltic extrusions. When the analyzed specimens are arranged stratigraphically, there is a sequence of peridotite-olivine gabbro $\left(8 \% \mathrm{Fe}_{2} \mathrm{O}_{3}, 10 \% \mathrm{MgO}\right)$-peridotite-eucrite $(6 \%$ $\left.\mathrm{Fe}_{2} \mathrm{O}_{3}, 18 \% \mathrm{MgO}\right)$-eucrite $\left(6.5 \% \mathrm{Fe}_{2} \mathrm{O}_{3}, 20 \% \mathrm{MgO}\right)$ peridotite-eucrite $\left(7 \% \mathrm{Fe}_{2} \mathrm{O}_{3}, 22 \% \mathrm{MgO}\right)$. The gabbros show increasing olivine content with depth. The stratigraphic sequence is reminiscent of a layered ultrabasic intrusion and argues against emplacement as a mélange. A cumulate origin is further indicated by the separation of the coarse-grained rocks from the basalts cn the variation diagrams (Figures 1, 3,4). Perhaps a better terminology than peridotite and eucrite is olivine-plagioclase cumulate and olivine-pyroxeneplagioclase cumulate.

In Figure 1 it is shown that the eucrites have the same $\mathrm{Fe} / \mathrm{Mg}$ ratio as the associated serpentinized peridotite. The eucrites cannot, therefore, represent a magmatic liquid from which olivine has concentrated to form the 
TABLE 4 - Continued

\begin{tabular}{|c|c|c|c|c|c|c|c|c|}
\hline & 37 & 38 & 39 & 40 & 41 & 42 & 43 & D. 1 \\
\hline $\mathrm{SiO}_{2}$ & 47.50 & 48.46 & 49.52 & 48.87 & 49.35 & 50.64 & 50.09 & 50.46 \\
\hline $\mathrm{Al}_{2} \mathrm{O}_{3}$ & 13.93 & 18.60 & 17.66 & 15.56 & 17.58 & 14.65 & 15.27 & 14.78 \\
\hline $\mathrm{TiO}_{2}$ & 0.599 & 0.555 & 0.908 & 0.633 & 0.868 & 1.129 & 0.975 & 1.173 \\
\hline $\mathrm{Fe}_{2} \mathrm{O}_{3}$ & 10.81 & 8.43 & 9.64 & 10.40 & 9.95 & 11.66 & 9.57 & 11.49 \\
\hline $\mathrm{MnO}$ & 0.166 & 0.143 & 0.160 & 0.164 & 0.152 & 0.169 & 0.162 & 0.176 \\
\hline $\mathrm{MgO}$ & 13.01 & 7.32 & 6.84 & 10.47 & 6.77 & 7.51 & 9.06 & 7.16 \\
\hline $\mathrm{CaO}$ & 11.86 & 14.36 & 12.69 & 11.92 & 12.38 & 11.90 & 11.87 & 12.01 \\
\hline $\mathrm{Na}_{2} \mathrm{O}$ & 1.84 & 1.88 & 2.15 & 1.86 & 2.51 & 2.08 & 2.68 & 2.25 \\
\hline $\mathrm{K}_{2} \mathrm{O}$ & 0.221 & 0.187 & 0.311 & 0.065 & 0.333 & 0.123 & 0.201 & 0.372 \\
\hline $\mathrm{P}_{2} \mathrm{O}_{5}$ & 0.06 & 0.06 & 0.12 & 0.06 & 0.11 & 0.13 & 0.12 & 0.13 \\
\hline Total & 99.996 & 99.995 & 99.999 & 100.002 & 100.003 & 99.991 & 99.998 & 100.001 \\
\hline $\mathrm{Ni}$ & 457.2 & 123.5 & 83.6 & 283.7 & 73.2 & 59.5 & 141.0 & 61.0 \\
\hline $\mathrm{Rb}$ & 3.5 & 2.4 & 4.9 & 1.2 & 5.5 & 2.0 & 2.2 & 7.7 \\
\hline $\mathrm{Sr}$ & 90.0 & 91.1 & 90.9 & 73.0 & 98.4 & 109.3 & 109.1 & 116.8 \\
\hline $\mathrm{Ba}$ & 48.9 & 51.8 & 62.0 & 42.8 & 69.7 & 70.3 & 74.5 & 70.8 \\
\hline \multicolumn{9}{|c|}{ CIPW Norms } \\
\hline $\mathrm{Qz}$ & 0.00 & 0.00 & 0.07 & 0.00 & 0.00 & 2.97 & 0.00 & 1.61 \\
\hline Or & 1.31 & 1.11 & 1.84 & 0.38 & 1.97 & 0.73 & 1.19 & 2.20 \\
\hline Plag & 44.67 & 57.67 & 55.81 & 49.66 & 56.96 & 47.88 & 51.72 & 48.17 \\
\hline Di & 23.53 & 23.50 & 19.96 & 19.99 & 20.33 & 22.74 & 23.42 & 24.13 \\
\hline $\mathrm{Hy}$ & 6.31 & 7.37 & 16.11 & 17.95 & 10.24 & 18.14 & 10.88 & 16.35 \\
\hline $\mathrm{O} 1$ & 18.18 & 5.47 & 0.00 & 6.13 & 4.27 & 0.00 & 6.48 & 0.00 \\
\hline Mt & 3.92 & 3.06 & 3.49 & 3.77 & 3.61 & 4.23 & 3.47 & 4.16 \\
\hline I1 & 1.14 & 1.05 & 1.72 & 1.20 & 1.65 & 2.14 & 1.85 & 2.23 \\
\hline Ap & 0.13 & 0.13 & 0.26 & 0.13 & 0.24 & 0.28 & 0.26 & 0.28 \\
\hline Total & 99.19 & 499.36 & 99.28 & 99.22 & 99.26 & 99.12 & 99.28 & 99.14 \\
\hline An $\%$ & 63.8 & 71.2 & 66.1 & 67.0 & 61.3 & 61.9 & 54.7 & 59.1 \\
\hline
\end{tabular}

peridotite, although these rocks are closely related mineralogically. Assuming the pyroxene to be a magnesian variety, the eucrites can be derived from the gabbro by accumulation of olivine, clinopyroxene, orthopyroxene, and bytownite, while the serpentinized peridotites may form by accumulation of olivine \pm minor pyroxene and plagioclase.

\section{Site 335}

The entire 107 meters of basalt drilled at this site belong to a single lithologic unit and the 130 glassy rinds in the 41.5 meters of recovered core indicate this to be a pillow lava pile. In terms of chemical variation, the 19 samples analyzed from this hole can be divided into seven stratigraphic units based on variations of $\mathrm{Al}_{2} \mathrm{O}_{3}, \mathrm{Fe}$, and $\mathrm{Ti}$ (Table 8 and Figure 11). Aside from minor variation, all of the lavas can be regarded as type 3 undifferentiated tholeiite and most are the low-Sr subtype. However, at two horizons the high-Sr subtype is present. If these latter samples are unaltered (as their chemistry suggests), then they may be dikes of a later magma cross-cutting the pillow-pile. The normative compositions of the 28 analyses have been plotted in the basalt tetrahedron (Figure 12), where they can be seen to form a simple magma series extending across the olivine tholeiite field. The few nepheline normative specimens contain abnormally high $\mathrm{CaO}$ probably due to the presence of secondary carbonate. Though the span in composition is small, good correlations between $\mathrm{P}_{2} \mathrm{O}_{5}-\mathrm{TiO}_{2}$ and negative correlation of alkalies$\mathrm{MgO}, \mathrm{CaO}-\mathrm{MgO}, \mathrm{Al}_{2} \mathrm{O}_{3}-\mathrm{MgO}$, coupled with the positive gradient of alumina with depth suggest that the range in composition is real. Both $\mathrm{K}_{2} \mathrm{O}$ and $\mathrm{Rb}$ are variable in the upper 48 meters of core, but from 480 to 540 meters $\mathrm{K}_{2} \mathrm{O}$ is constant near $0.3 \%$ and $\mathrm{Rb}$ at $5 \mathrm{ppm}$.

\section{DISCUSSION}

The igneous stratigraphy of the five drill holes and the 217 analyzed samples presents a unique opportunity to characterize nonregionally metamorphosed and nonorogenically deformed oceanic crust. In terms of the number of samples analyzed at Montreal the proportions of the different rocks are:

\begin{tabular}{lcrrr}
\hline & \multicolumn{2}{c}{ No. } & \multicolumn{2}{c}{ No. } \\
& Samples & $(\%)$ & Analyses & $(\%)$ \\
\hline Undifferentiated tholeiite & 98 & 44 & 125 & 44 \\
Plagioclase basalt & 80 & 36 & 101 & 36 \\
Picritic basalts and picrite & 35 & 16 & 45 & 16 \\
Coarse-grained rocks & 10 & 4 & 13 & 5 \\
\hline
\end{tabular}

The relative proportions based on the chemical stratigraphy are: 


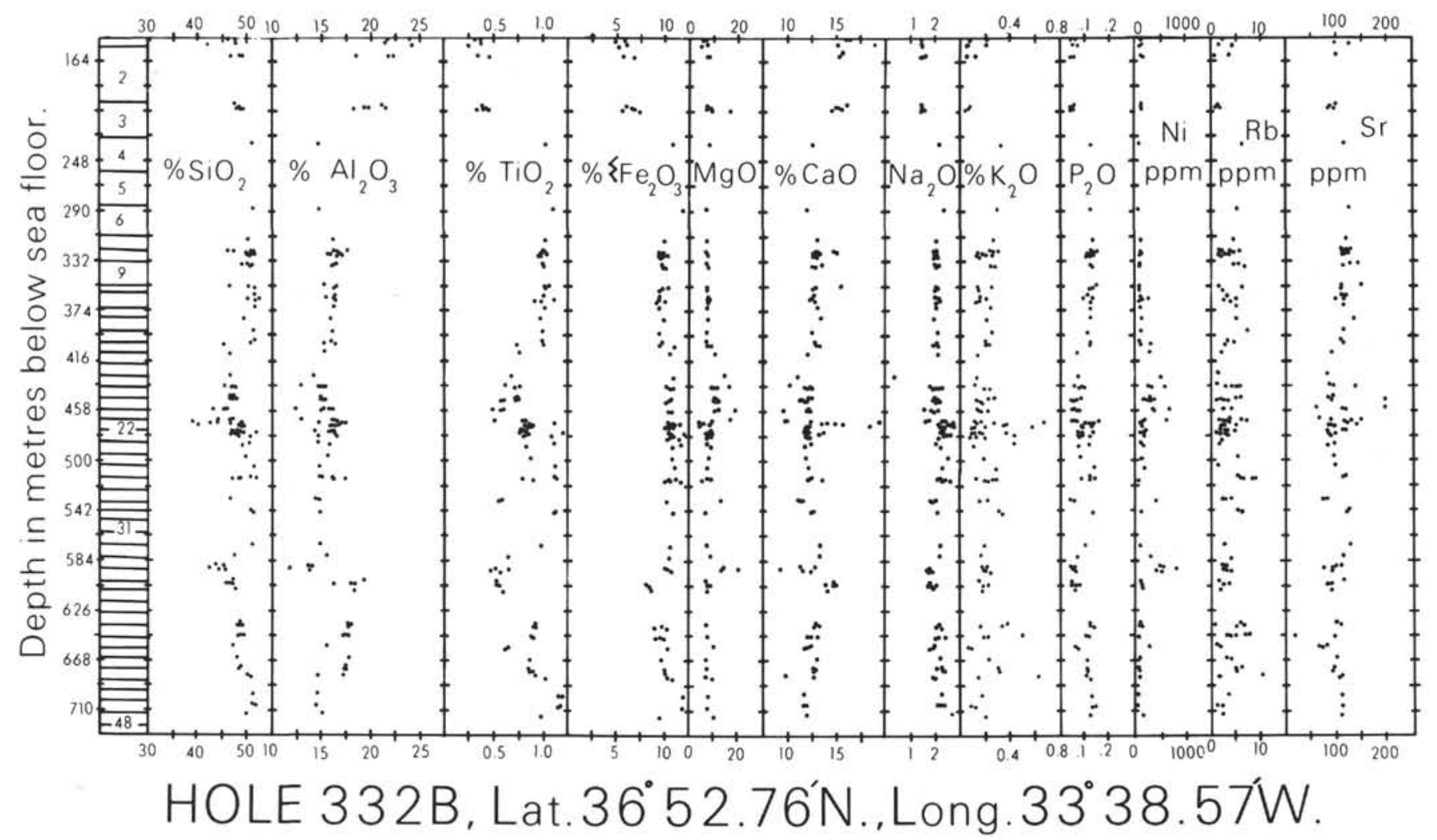

Figure 7. Oxide and elemental variation with depth for Hole 332B.

$\begin{array}{lrl}\text { Undifferentiated tholeiite } & 694 \mathrm{~m}=63 \% \\ \text { Plagioclase basalt } & 284 \mathrm{~m}=26 \% \\ \text { Picritic basalts and picrites } & 72 \mathrm{~m}=7 \% \\ \text { Coarse-grained rocks } & 57 \mathrm{~m}=5 \%\end{array}$

One of the most striking features of the five holes is their heterogeneous nature. Obvious plagioclase basalts are restricted to Holes $332 \mathrm{~B}$ and $332 \mathrm{~A}$. The few occurrences named here in Holes 333A and 335 have close to $16 \% \mathrm{Al}_{2} \mathrm{O}_{3}$, yet could also be regarded as tholeiites as the $\% \mathrm{Al}_{2} \mathrm{O}_{3}$ above $16 \%$ lies within the limits of analytical variation. Tholeiite predominates in Holes $332 \mathrm{~A}, 332 \mathrm{D}, 333 \mathrm{~A}$, and Sites 334 and 335, yet plagioclase basalt predominates in Hole 332B. Picritic basalts and picrites comprise a small percentage of the rocks of Holes 332A, 332B, and 333A. Almost every hole can be regarded as being unique in one respect or another. Hole 332B because of the predominance of porphyritic lavas, $332 \mathrm{~A}$ and $333 \mathrm{~A}$ by the dominance of undifferentiated tholeiite, 334 by the presence of coarse-grained rocks, probably layered cumulates, and 335 by its simple and monotonous lithology.

In terms of the parentage of the magmas the picture presented is of a large number of slightly different tholeiites-perhaps about 4 or 5 types for the five holes-each differing slightly in content of $\mathrm{TiO}_{2}, \mathrm{~K}_{2} \mathrm{O}$, and $\mathrm{P}_{2} \mathrm{O}_{5}$ due to variations in the primary melt. Some of these have in turn undergone fractionation of one or more of the phenocryst minerals to produce plagioclase- and olivine-enriched series, which also differ in their $\mathrm{TiO}_{2}, \mathrm{~K}_{2} \mathrm{O}$, and $\mathrm{P}_{2} \mathrm{O}_{5}$ content depending on the parent. Residual liquids impoverished in olivine and plagioclase are only very sparsely present in the holes, while evidence of pyroxene fractionation is not readily seen.

Although the variation diagrams presented here are apparently simple, a closer scrutiny reveals that the trends are in fact composites of shorter, subparallel trends each of which reflects different stratigraphic units in different holes. It is the combination of these which results in the apparently simple picture, which also indicates that olivine and plagioclase fractionation has operated repeatedly in different chambers of tholeiite magma.

It must be emphasized that studies of this kind involving distinguishing between a range of primary melts differing by only tenths of a percent titania and phosphate and by tens of $\mathrm{ppm} \mathrm{Sr}$ require a high degree of analytical precision. In this study, the small size of samples taken coupled with the unknown degree of alteration and the lack of complementary X-ray diffraction analysis has substantially reduced the value of the study.

However, we believe that this study has begun to define the real compositions of possible primary basaltic liquids forming the oceanic crust and some of the possible secondary modifying fractionation processes.

\section{REFERENCES}

Abbey, S., 1973. Studies in "standard samples" of silicate rocks and minerals. Part 3. 1973 extension and revision of "usable" tables: Canadian Geol. Surv. Publ., p. 1-24.

Bhattacharji, S., 1967. Mechanics of flow differentiation in ultramafic and mafic sills: J. Geol., v. 75, p. 101-112. 
TABLE 5

Average Compositions for Montreal Chemical Groups of Hole 332A

\begin{tabular}{|c|c|c|c|c|c|c|c|c|c|c|c|}
\hline & 1 & 2 & 3 & 4 & 5 & 6 & 7 & 8 & 9 & 10 & 11 \\
\hline $\mathrm{SiO}_{2}$ & 50.65 & 48.78 & 50.34 & 50.32 & 51.03 & 50.69 & 50.81 & 49.37 & 50.30 & 48.72 & 48.71 \\
\hline $\mathrm{Al}_{2} \mathrm{O}_{3}$ & 14.73 & 22.21 & 14.64 & 15.14 & 14.46 & 14.82 & 14.77 & 15.15 & 16.36 & 17.07 & 15.45 \\
\hline $\mathrm{TiO}_{2}$ & 0.889 & 0.364 & 1.151 & 1.218 & 1.130 & 0.906 & 1.079 & 1.243 & 1.022 & 0.557 & 0.534 \\
\hline $\mathrm{Fe}_{2} \mathrm{O}_{3}$ & 10.10 & 5.33 & 11.50 & 11.10 & 11.33 & 9.77 & 10.62 & 11.25 & 9.72 & 7.25 & 7.54 \\
\hline $\mathrm{MnO}$ & 0.167 & 0.081 & 0.173 & 0.169 & 0.175 & 0.137 & 0.173 & 0.169 & 0.153 & 0.123 & 0.127 \\
\hline $\mathrm{MgO}$ & 7.44 & 5.62 & 7.17 & 7.40 & 7.15 & 8.56 & 7.35 & 7.21 & 7.10 & 9.38 & 11.79 \\
\hline $\mathrm{CaO}$ & 13.60 & 15.89 & 12.40 & 12.09 & 11.99 & 12.88 & 12.60 & 12.92 & 12.91 & 15.17 & 14.29 \\
\hline $\mathrm{Na}_{2} \mathrm{O}$ & 2.09 & 1.57 & 2.10 & 2.08 & 2.25 & 2.01 & 2.17 & 2.24 & 2.03 & 1.52 & 1.39 \\
\hline $\mathrm{K}_{2} \mathrm{O}$ & 0.248 & 0.109 & 0.383 & 0.327 & 0.367 & 0.120 & 0.303 & 0.290 & 0.282 & 0.137 & 0.102 \\
\hline $\mathrm{P}_{2} \mathrm{O}_{5}$ & 0.09 & 0.05 & 0.14 & 0.15 & 0.12 & 0.10 & 0.12 & 0.17 & 0.12 & 0.07 & 0.07 \\
\hline Total & 100.004 & 100.004 & 99.997 & 99.994 & 100.002 & 99.993 & 99.995 & 100.012 & 99.997 & 99.997 & 100.003 \\
\hline $\mathrm{Ni}$ & 68.8 & 91.1 & 66.9 & 91.4 & 58.1 & 76.9 & 72.1 & 95.4 & 83.6 & 190.1 & 261.5 \\
\hline $\mathrm{Rb}$ & 4.6 & 2.0 & 5.5 & 6.1 & 6.2 & 1.8 & 5.2 & 5.5 & 5.9 & 2.7 & 2.0 \\
\hline Sr & 105.5 & 110.0 & 107.7 & 113.3 & 116.2 & 107.1 & 114.7 & 117.3 & 109.6 & 108.1 & 95.2 \\
\hline $\mathrm{Ba}$ & 50.3 & 31.4 & 61.5 & 67.7 & 70.8 & 64.5 & 66.3 & 70.3 & 57.7 & 43.5 & 43.2 \\
\hline \multicolumn{12}{|c|}{ CIPW Norms } \\
\hline $\mathrm{Qz}$ & 1.28 & 0.09 & 1.83 & 2.03 & 2.45 & 1.37 & 1.99 & 0.00 & 1.72 & 0.00 & 0.00 \\
\hline Or & 1.47 & 0.64 & 2.26 & 1.93 & 2.17 & 0.71 & 1.79 & 1.71 & 1.67 & 0.81 & 0.60 \\
\hline Plag & 47.77 & 66.52 & 47.16 & 48.61 & 47.31 & 48.07 & 48.03 & 49.38 & 51.87 & 52.21 & 47.38 \\
\hline $\mathrm{Di}$ & 29.85 & 20.32 & 25.45 & 22.78 & 24.79 & 25.98 & 26.05 & 26.52 & 23.18 & 28.36 & 27.76 \\
\hline $\mathrm{Hy}$ & 13.34 & 9.30 & 15.77 & 17.14 & 15.91 & 17.65 & 15.18 & 14.17 & 15.10 & 8.19 & 11.01 \\
\hline 01 & 0.00 & 0.00 & 0.00 & 0.00 & 0.00 & 0.00 & 0.00 & 0.57 & 0.00 & 6.04 & 8.78 \\
\hline Mt & 3.66 & 1.93 & 4.17 & 4.02 & 4.11 & 3.54 & 3.85 & 4.08 & 3.52 & 2.63 & 2.73 \\
\hline I1 & 1.69 & 0.69 & 2.19 & 2.31 & 2.15 & 1.72 & 2.05 & 2.36 & 1.94 & 1.06 & 1.01 \\
\hline Ap & 0.20 & 0.11 & .0 .31 & 0.33 & 0.26 & 0.22 & 0.26 & 0.37 & 0.26 & 0.15 & 0.15 \\
\hline Total & 99.25 & 99.60 & 99.13 & 99.16 & 99.15 & 99.26 & 99.20 & 99.17 & 99.27 & 99.45 & 99.44 \\
\hline An \% & 61.6 & 79.1 & 60.9 & 62.4 & 58.3 & 63.3 & 60.4 & 60.2 & 65.6 & 74.3 & 74.1 \\
\hline
\end{tabular}

Note: 1 . Type 2 tholeiite, 1 analysis. 2. Low-Ti, plagioclase basalt, 1 analysis. 3 . Type 3 tholeiite, average of 4 analyses. 4 . Type 4 tholeiite, 1 analysis. 5. Type 3 tholeiite, average of 4 analyses. 6 . Type 2 tholeiite, 1 analysis. 7 . Type 3 tholeiite, average of 9 analyses. 8 . Type 4 tholeiite, average of 4 analyses. 9 . High- $\mathrm{Ti}$, plagioclase basalt, average of 3 analyses. 10. Low-Ti, plagioclase basalt, average of 3 analyses. 11. Low-Ti, picritic basalt, average of 4 analyses.

Clarke, D.B., 1970. Tertiary basalts from Baffin Bay: possible primary magma from the mantle: Contrib. Mineral. Petrol., v. 25, p. 203-224.

Flanagan, F.J., 1973. 1972 values for international geochemical reference samples: Geochim. Cosmochim. Acta, v. 37 , p. $1189-1200$

Gunn, B.M., Watkins, N.D., Trzcienski, Jr., W.E., and Nougier, J., 1975. The Amsterdam-St. Paul volcanic province, and the formation of low-Al, tholeiitic andesites: Lithos, v. 13, p. 61-73.

Gunn, B.M. and Watkins, N.D., in press. The geochemistry of the Cape Verdes and Fernando de Noronha: Geol. Soc. Am. Bull.

MacDonald, G.A., 1968. A contribution to the petrology of Tutuila, American Samoa: Geol. Rundschau, v. 57, p. $821-836$.
Murata, K.J. and Richter, D.H., 1966. The settling of olivine in Kilauea magma as shown by lavas of the 1959 eruption: Am. J. Sci., v. 264, p. 194-203.

Rex, R.W., 1967. Authigenic silicates formed from basaltic glass by more than 60 million years contact with sea water, Sylvania guyot, Marshall Islands: 15th Natl. Conf. Clay Clay Minerals Proc., p. 195-203.

Wager, L.R. and Brown, G.M., 1968. Layered igneous rocks: London (Oliver \& Boyd).

Wright, T.L., 1971. Chemistry of Kilauea and Mauna Loa lavas in space and time: U.S. Geol. Surv. Prof. Paper, 735, p. 1-40. 


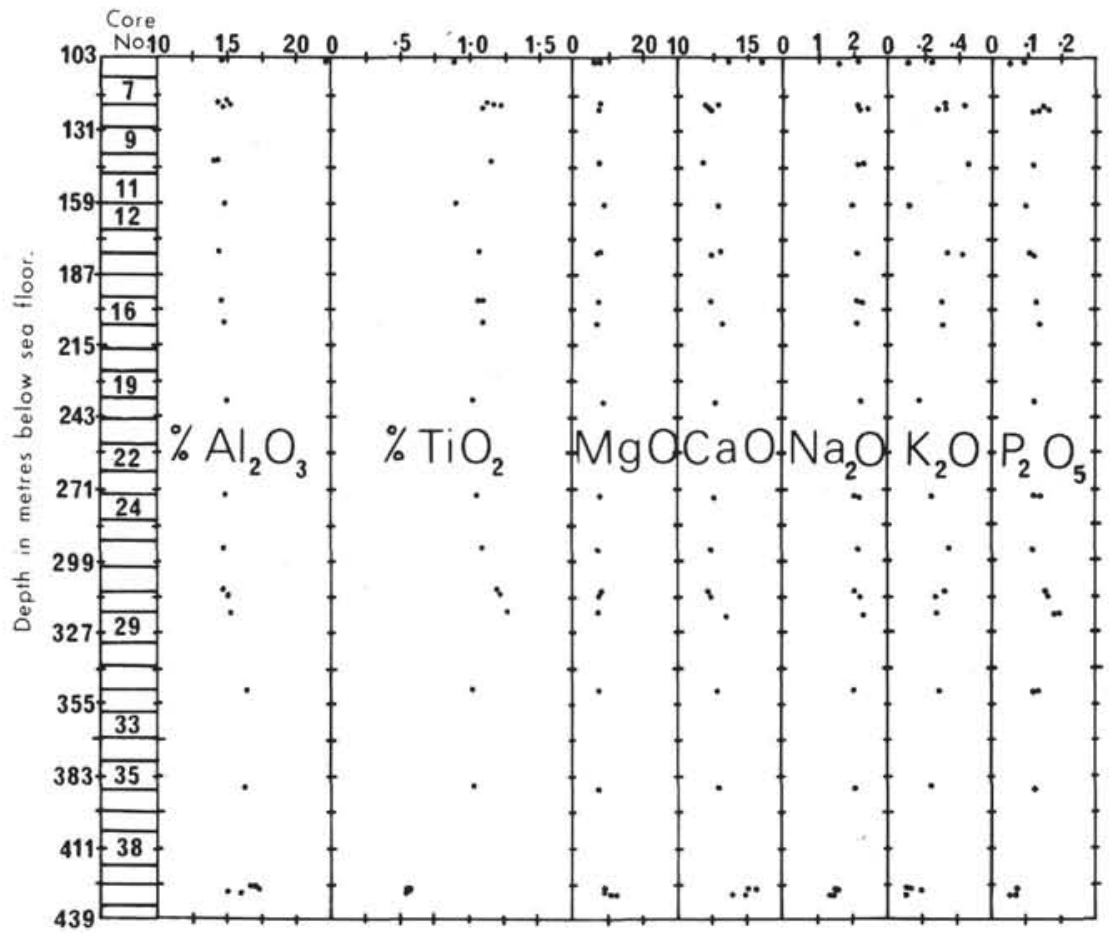

HOLE 332A. Lat. $36^{\circ} 52.72^{\prime} \mathrm{N}$..Long. $33^{\circ} 38.46^{\mathrm{W}}$.

Figure 8. Oxide and elemental variation with depth for Hole $332 \mathrm{~A}$.

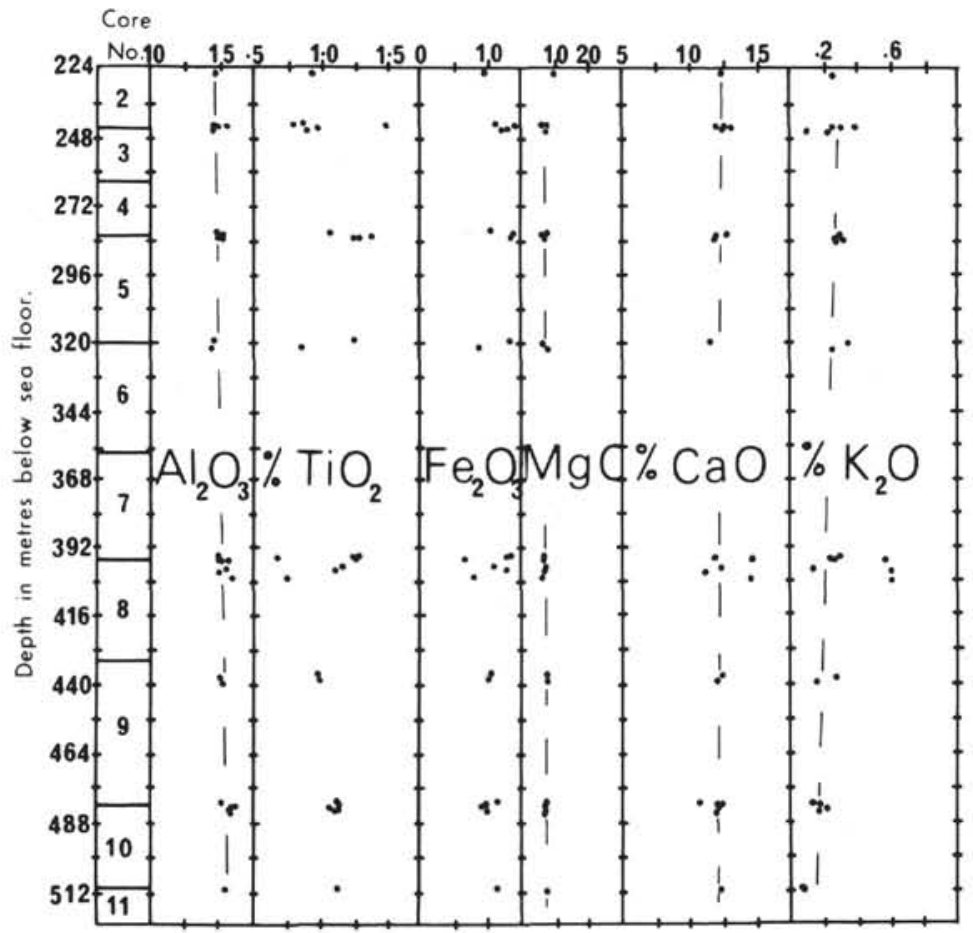

HOLE 333A, Lat. $36^{\circ} 50.45^{\prime} \mathrm{N}$.,Long. $33^{\circ} 40.05^{\prime} \mathrm{W}$.

Figure 9. Oxide and elemental variation with depth for Hole $333 \mathrm{~A}$. 
TABLE 6

Average Compositions for Montreal Chemical Groups of Hole 333A

\begin{tabular}{|c|c|c|c|c|c|c|c|c|c|c|c|}
\hline & 1 & 2 & 3 & 4 & 5 & 6 & 7 & 8 & 9 & 10 & 11 \\
\hline $\mathrm{SiO}_{2}$ & 50.03 & 49.87 & 50.45 & 49.76 & 48.09 & 49.53 & 49.49 & 49.80 & 48.72 & 50.17 & 50.58 \\
\hline $\mathrm{Al}_{2} \mathrm{O}_{3}$ & 14.51 & 14.76 & 14.79 & 15.03 & 14.55 & 15.09 & 15.76 & 15.30 & 16.06 & 15.16 & 15.62 \\
\hline $\mathrm{TiO}_{2}$ & 0.917 & 1.493 & 0.902 & 1.257 & 0.871 & 1.279 & 0.685 & 1.146 & 0.756 & 0.978 & 1.110 \\
\hline $\mathrm{Fe}_{2} \mathrm{O}_{3}$ & 9.64 & 12.10 & 10.96 & 11.52 & 9.50 & 11.65 & 8.40 & 11.08 & 9.10 & 10.32 & 10.17 \\
\hline $\mathrm{MnO}$ & 0.151 & 0.183 & 0.169 & 0.166 & 0.267 & 0.183 & 0.162 & 0.170 & 0.128 & 0.281 & 0.141 \\
\hline $\mathrm{MgO}$ & 10.09 & 6.74 & 7.62 & 7.59 & 8.75 & 7.60 & 7.99 & 7.96 & 7.51 & 8.23 & 7.91 \\
\hline $\mathrm{CaO}$ & 12.44 & 11.98 & 12.61 & 12.10 & 15.94 & 11.99 & 14.77 & 11.85 & 14.79 & 12.46 & 12.04 \\
\hline $\mathrm{Na}_{2} \mathrm{O}$ & 1.85 & 2.28 & 2.23 & 2.10 & 1.64 & 2.23 & 2.07 & 2.15 & 2.21 & 2.00 & 2.13 \\
\hline $\mathrm{K}_{2} \mathrm{O}$ & 0.239 & 0.386 & 0.197 & 0.312 & 0.266 & 0.284 & 0.578 & 0.386 & 0.617 & 0.287 & 0.159 \\
\hline $\mathrm{P}_{2} \mathrm{O}_{5}$ & 0.12 & 0.20 & 0.09 & 0.16 & 0.12 & 0.17 & 0.09 & 0.14 & 0.10 & 0.12 & 0.13 \\
\hline Total & 99.987 & 99.992 & 100.018 & 99.995 & 99.994 & 100.006 & 99.995 & 99.982 & 99.991 & 100.006 & 99.990 \\
\hline $\mathrm{Ni}$ & 238.3 & 100.8 & 76.7 & 99.7 & 204.5 & 88.3 & 118.2 & 99.6 & 96.5 & 85.3 & 101.2 \\
\hline $\mathrm{Rb}$ & 4.4 & 7.3 & 3.8 & 6.0 & 6.7 & 4.3 & 5.7 & 5.7 & 6.2 & 4.3 & 2.9 \\
\hline $\mathrm{Sr}$ & 117.2 & 120.3 & 96.0 & 116.9 & 119.0 & 116.3 & 104.8 & 114.8 & 113.0 & 118.0 & 114.8 \\
\hline $\mathrm{Ba}$ & 75.7 & 83.3 & 68.0 & 82.1 & 65.8 & 70.9 & 71.8 & 66.8 & 84.4 & 130.6 & 87.6 \\
\hline \multicolumn{12}{|c|}{ CIPW Norms } \\
\hline Qz & 0.00 & 1.54 & 0.92 & 1.04 & 0.00 & 0.29 & 0.00 & 0.25 & 0.00 & 0.80 & 1.95 \\
\hline Or & 1.41 & 2.28 & 1.16 & 1.84 & 1.57 & 1.68 & 3.42 & 2.28 & 3.65 & 1.70 & 0.94 \\
\hline Plag & 46.24 & 48.19 & 48.64 & 48.43 & 45.43 & 49.20 & 49.52 & 49.15 & 48.49 & 48.47 & 50.62 \\
\hline $\mathrm{Ne}$ & 0.00 & 0.00 & 0.00 & 0.00 & 0.00 & 0.00 & 0.00 & 0.00 & 1.24 & 0.00 & 0.00 \\
\hline Di & 24.41 & 23.92 & 26.17 & 23.06 & 37.70 & 22.85 & 32.78 & 21.87 & 32.86 & 23.90 & 21.30 \\
\hline $\mathrm{Hy}$ & 20.59 & 15.50 & 16.42 & 17.84 & 0.69 & 18.09 & 1.69 & 19.10 & 0.00 & 18.51 & 18.34 \\
\hline $\mathrm{Ol}$ & 1.12 & 0.00 & 0.00 & 0.00 & 8.52 & 0.00 & 7.41 & 0.00 & 8.11 & 0.00 & 0.00 \\
\hline Mt & 3.49 & 4.39 & 3.97 & 4.18 & 3.44 & 4.22 & 3.04 & 4.02 & 3.30 & 3.74 & 3.69 \\
\hline Il & 1.74 & 2.84 & 1.71 & 2.39 & 1.65 & 2.43 & 1.30 & 2.18 & 1.44 & 1.86 & 2.11 \\
\hline Ap & 0.26 & 0.44 & 0.20 & 0.35 & 0.26 & 0.37 & 0.20 & 0.31 & 0.22 & 0.26 & 0.28 \\
\hline Total & 99.26 & 99.08 & 99.20 & 99.13 & 99.28 & 99.13 & 99.37 & 99.15 & 99.31 & 99.23 & 99.23 \\
\hline An $\%$ & 64.8 & 58.5 & 59.8 & 61.9 & 68.2 & 60.2 & 63.3 & 61.6 & 64.8 & 63.7 & 63.0 \\
\hline
\end{tabular}

Note: 1. High-Ti, picritic basalt, average of 2 analyses. 2. Type 4 tholeiite, 1 analysis. 3 . Type 2 tholeiite, average of 5 analyses. 4. Type 3 tholeiite, average of 5 analyses. 5. Type 2 tholeiite, 1 analysis. 6 . Type 4 tholeiite, average of 3 analyses. 7. Type 1 tholeiite, 1 analysis. 8. Type 3 tholeiite, average of 2 analyses. 9. High-Ti, plagioclase basalt, 1 analysis. 10 . Type 2 tholeiite, 1 analysis. 11. Type 3 tholeiite, average of 9 analyses. 
TABLE 7

Average Compositions for Montreal Chemical Groups of Hole 334

\begin{tabular}{|c|c|c|c|c|c|c|c|c|c|}
\hline No. & 1 & 2 & 3 & 4 & 5 & 6 & 7 & 8 & 9 \\
\hline $\mathrm{SiO}_{2}$ & 51.17 & 50.87 & 44.85 & 50.71 & 44.04 & 50.85 & 48.43 & 44.75 & 48.34 \\
\hline $\mathrm{Al}_{2} \mathrm{O}_{3}$ & 15.41 & 15.00 & 4.79 & 15.58 & 3.99 & 12.32 & 11.87 & 5.46 & 10.41 \\
\hline $\mathrm{TiO}_{2}$ & 0.882 & 0.747 & 0.070 & 0.145 & 0.039 & 0.086 & 0.70 & 0.45 & 0.067 \\
\hline $\mathrm{Fe}_{2} \mathrm{O}_{3}$ & 10.14 & 9.88 & 10.78 & 8.18 & 10.72 & 5.73 & 6.57 & 9.63 & 6.90 \\
\hline $\mathrm{MnO}$ & 0.163 & 0.166 & 0.150 & 0.168 & 0.116 & 0.121 & 0.120 & 0.157 & 0.163 \\
\hline $\mathrm{MgO}$ & 7.58 & 8.37 & 36.53 & 10.26 & 39.64 & 18.05 & 20.08 & 35.04 & 22.08 \\
\hline $\mathrm{Na}_{2} \mathrm{O}$ & 1.99 & 1.76 & 0.11 & 1.18 & 0.14 & 0.50 & 0.32 & 0.11 & 0.27 \\
\hline $\mathrm{K}_{2}$ & 0.298 & 0.166 & 0.016 & 0.021 & 0.032 & 0.014 & 0.038 & 0.012 & 0.058 \\
\hline $\mathrm{P}_{2} \mathrm{O}_{5}$ & 0.11 & 0.08 & 0.01 & 0.02 & 0.03 & 0.02 & 0.02 & 0.01 & 0.02 \\
\hline Total & 100.023 & 99.999 & 99.996 & 99.994 & 100.007 & 100.011 & 100.018 & 100.004 & 100.008 \\
\hline $\mathrm{Ni}$ & 137.5 & 142.7 & 1991.8 & 152.9 & 1648.5 & 456.2 & 627.0 & 1828.6 & 780.4 \\
\hline $\mathrm{Rb}$ & 5.4 & 3.1 & .5 & 1.2 & 1.2 & .5 & .6 & .8 & 1.3 \\
\hline $\mathrm{Sr}$ & 85.0 & 70.8 & 2.1 & 30.2 & 4.9 & 11.4 & 14.2 & 4.2 & 12.8 \\
\hline $\mathrm{Ba}$ & 88.5 & 68.0 & 32.9 & 45.1 & 78.9 & 53.5 & 0.0 & 47.3 & 59.3 \\
\hline \multicolumn{10}{|c|}{ CIPW NORMS } \\
\hline $\mathrm{Qz}$ & 2,93 & 2.48 & 0.00 & 1.88 & 0.00 & 0.00 & 0.00 & 0.00 & 0.00 \\
\hline Or & 1.76 & 0.98 & 0.09 & 0.12 & 0.19 & 0.08 & 0.22 & 0.07 & 0.34 \\
\hline Plag & 49.08 & 47.43 & 13.46 & 47.14 & 7.26 & 35.56 & 33.55 & 15.30 & 29.31 \\
\hline $\mathrm{Di}$ & 22.69 & 25.25 & 9.60 & 24.72 & 0.00 & 23.41 & 24.51 & 7.35 & 24.38 \\
\hline $\mathrm{Hy}$ & 17.21 & 17.93 & 29.86 & 22.23 & 28.72 & 34.13 & 22.40 & 21.96 & 23.18 \\
\hline $\mathrm{Ol}$ & 0.00 & 0.00 & 51.12 & 0.00 & 57.51 & 4.12 & 16.29 & 51.00 & 19.60 \\
\hline $\mathrm{Mt}$ & 3.68 & 3.58 & 3.91 & 2.97 & 3.89 & 2.08 & 2.38 & 3.49 & 2.50 \\
\hline II & 1.68 & 1.42 & 0.13 & 0.28 & 0.07 & 0.16 & 0.13 & 0.09 & 0.13 \\
\hline $\mathrm{Ap}$ & 0.24 & 0.17 & 0.02 & 0.04 & 0.07 & 0.04 & 0.04 & 0.02 & 0.04 \\
\hline Cor & 0.00 & 0.00 & 0.00 & 0.00 & 1.50 & 0.00 & 0.00 & 0.00 & 0.00 \\
\hline Total & 99.26 & 99.26 & 99.19 & 99.38 & 99.20 & 99.58 & 99.53 & 99.28 & 99.49 \\
\hline An $\%$ & 64.3 & 67.3 & 92.7 & 77.8 & 82.9 & 87.5 & 91.5 & 93.6 & 91.8 \\
\hline
\end{tabular}

Note: 1. Type 2 tholeiite, average of 6 analyses. 2. Type 1 tholeiite, average of 16 analyses. 3. Peridotite, 1 analyses. 4. Gabrro, average of 4 analyses. 5. Peridotite, 1 analysis. 6. Eucrite, average of 3 analyses. 7. Eucrite, average of 2 analyses. 8. Peridotite, 1 analysis. 9. Eucrite, average of 2 analyses. 
TABLE 8

Average Compositions for Montreal Chemical Groups of Hole 335

\begin{tabular}{|c|c|c|c|c|c|c|c|c|}
\hline & 1 & 2 & 3 & 4 & 5 & 6 & 7 & 8 \\
\hline $\mathrm{SiO}_{2}$ & 49.48 & 49.17 & 49.47 & 49.74 & 50.17 & 49.26 & 49.45 & 49.49 \\
\hline $\mathrm{Al}_{2} \mathrm{O}_{3}$ & 15.56 & 16.08 & 15.93 & 16.31 & 15.90 & 16.22 & 15.84 & 15.82 \\
\hline $\mathrm{TiO}_{2}$ & 1.140 & 1.110 & 1.083 & 1.045 & 1.062 & 1.114 & 1.111 & 1.108 \\
\hline $\mathrm{Fe}_{2} \mathrm{O}_{3}$ & 1038 & 10.49 & 9.87 & 9.77 & 9.91 & 10.21 & 10.52 & 10.19 \\
\hline $\mathrm{MnO}$ & 0.157 & 0.168 & 0.162 & 0.147 & 0.152 & 0.166 & 0.159 & 0.159 \\
\hline $\mathrm{MgO}$ & 8.08 & 7.87 & 7.78 & 7.87 & 8.01 & 6.97 & 7.64 & 7.87 \\
\hline $\mathrm{CaO}$ & 12.42 & 12.37 & 12.87 & 12.42 & 12.14 & 13.14 & 12.40 & 12.56 \\
\hline $\mathrm{Na}_{2} \mathrm{O}$ & 2.38 & 2.39 & 2.43 & 2.30 & 2.25 & 2.48 & 2.47 & 2.40 \\
\hline $\mathrm{K}_{2} \mathrm{O}$ & 0.291 & 0.257 & 0.292 & 0.277 & 0.292 & 0.308 & 0.304 & 0.290 \\
\hline $\mathrm{P}_{2} \mathrm{O}_{5}$ & 0.12 & 0.11 & 0.11 & 0.10 & 0.11 & 0.13 & 0.12 & 0.12 \\
\hline Total & 100.009 & 100.015 & 99.997 & 99.979 & 99.996 & 99.998 & 100.014 & 100.007 \\
\hline $\mathrm{Ni}$ & 169.2 & 169.2 & 167.5 & 153.6 & 0.0 & 155.9 & 151.7 & 165.0 \\
\hline $\mathrm{Rb}$ & 5.1 & 5.2 & 5.2 & 2.9 & 4.5 & 5.4 & 5.2 & 5.0 \\
\hline $\mathrm{Sr}$ & 93.2 & 89.1 & 97.0 & 145.4 & 89.6 & 97.6 & 93.0 & 98.1 \\
\hline $\mathrm{Ba}$ & 74.0 & 74.9 & 68.3 & 96.3 & 65.5 & 50.6 & 60.8 & 71.4 \\
\hline \multicolumn{9}{|c|}{ CIPW Norms } \\
\hline $\mathrm{Qz}$ & 0.00 & 0.00 & 0.00 & 0.00 & .16 & 0.00 & 0.00 & 0.00 \\
\hline Or & 1.72 & 1.52 & 1.73 & 1.64 & 1.73 & 1.82 & 1.80 & 1.71 \\
\hline Plag & 51.06 & 52.61 & 52.26 & 51.46 & 51.46 & 53.20 & 52.14 & 51.85 \\
\hline Di & 24.22 & 22.91 & 25.43 & 22.32 & 21.91 & 26.11 & 23.93 & 24.29 \\
\hline Hy & 12.10 & 11.33 & 9.16 & 14.76 & 18.14 & 7.49 & 10.98 & 11.36 \\
\hline $\mathrm{O} 1$ & 3.95 & 4.71 & 4.80 & 1.95 & 0.00 & 4.51 & 4.19 & 3.98 \\
\hline $\mathrm{Mt}$ & 3.76 & 3.80 & 3.58 & 3.54 & 3.59 & 3.70 & 3.81 & 3.69 \\
\hline I1 & 2.17 & 2.11 & 2.06 & 1.98 & 2.02 & 2.12 & 2.11 & 2.10 \\
\hline Ap & 0.26 & 0.24 & 0.24 & 0.22 & 0.24 & 0.28 & 0.26 & 0.26 \\
\hline Total & 99.23 & 99.23 & 99.26 & 99.25 & 99.25 & 99.23 & 99.23 & 99.24 \\
\hline An $\%$ & 59.1 & 60.2 & 59.2 & 61.8 & 61.6 & 59.1 & 58.5 & 59.4 \\
\hline
\end{tabular}

Note: 1 . Type 3 tholeiite, average of 11 analyses. 2. High-Ti, plagioclase basalt, average of 2 analyses. 3. Type 3 tholeiite, average of 8 analyses. 4 . High-Ti, plagioclase basalt, average of 2 analyses. 5. Type 3 tholeiite, 1 analysis. 6 . High-Ti, plagioclase basalt, 1 analysis. 7 . Type 3 tholeiite, average of 3 analyses. 8 . Average of 28 analyses of Hole 335 pillow lava. 


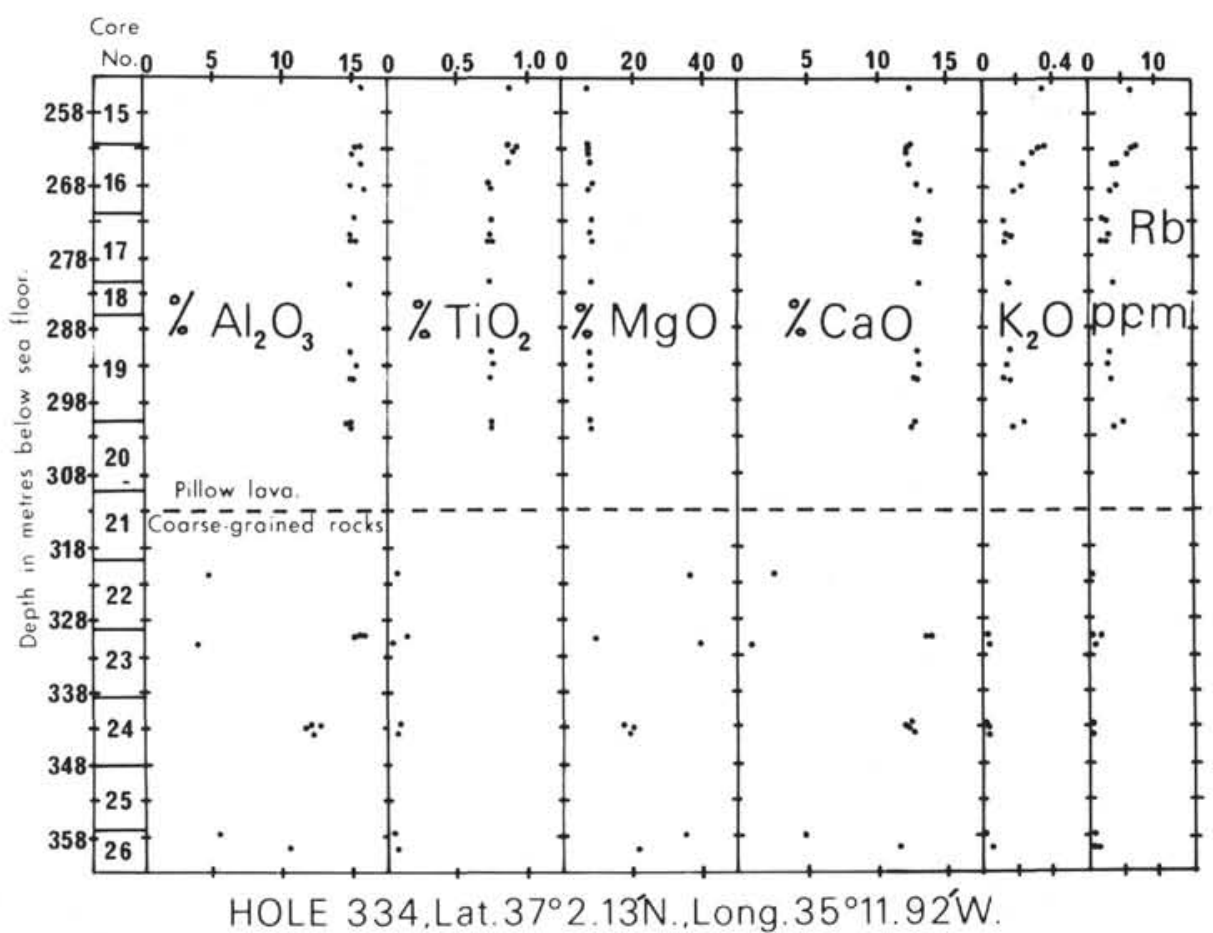

Figure 10. Oxide and elemental variation with depth for Site 334.
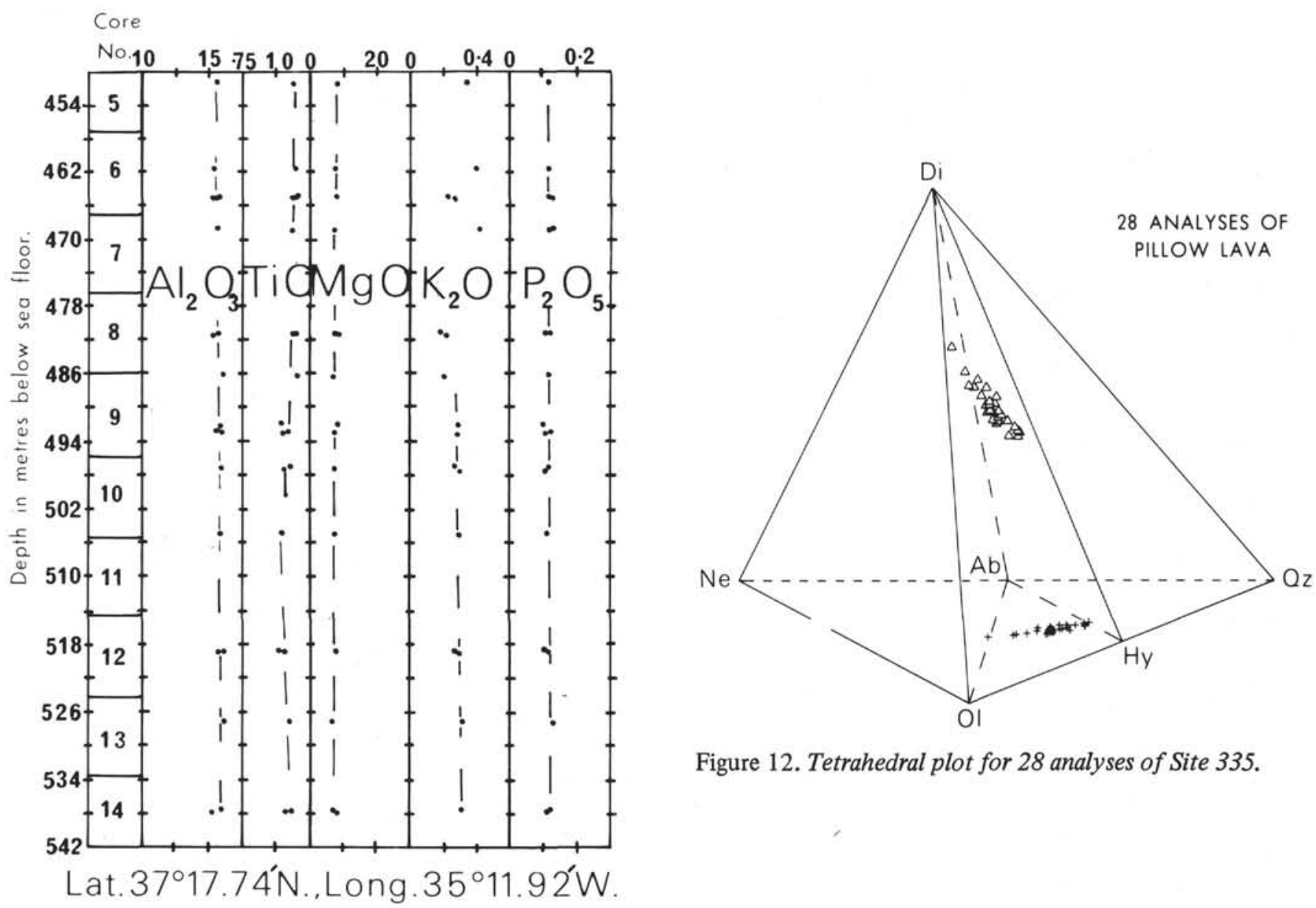

Figure 12. Tetrahedral plot for 28 analyses of Site 335.

Figure 11. Oxide and elemental variation with depth for Site 335. 